\title{
Developmental Dynamics: Toward a Biologically Plausible Evolutionary Psychology
}

\author{
Robert Lickliter \\ Florida International University
}

\author{
Hunter Honeycutt \\ Indiana University Bloomington
}

\begin{abstract}
There has been a conceptual revolution in the biological sciences over the past several decades. Evidence from genetics, embryology, and developmental biology has converged to offer a more epigenetic, contingent, and dynamic view of how organisms develop. Despite these advances, arguments for the heuristic value of a gene-centered, predeterministic approach to the study of human behavior and development have become increasingly evident in the psychological sciences during this time. In this article, the authors review recent advances in genetics, embryology, and developmental biology that have transformed contemporary developmental and evolutionary theory and explore how these advances challenge gene-centered explanations of human behavior that ignore the complex, highly coordinated system of regulatory dynamics involved in development and evolution.
\end{abstract}

The prestige of success enjoyed by the gene theory might become a hindrance to the understanding of development by directing our attention solely to the genome. ... Already we have theories that refer the processes of development to genic action and regard the whole performance as no more than the realization of the potencies of the genes. Such theories are altogether too one-sided. (Harrison, 1937, p. 370)

There is growing consensus in popular culture that by understanding genes and the mutual interactions of the proteins derived from them it is possible to understand all of life, including human nature. Psychology is no stranger to this perspective. As most psychologists are aware, a blend of ethology and sociobiology known as evolutionary psychology has gained increasing attention and recognition over the past several decades. Arguments for the heuristic value of a gene-centered, evolutionary approach to the study of human behavior have become increasingly evident in mainstream psychology journals (i.e., Buss, 1995; Buss \& Schmitt, 1993; Buss \& Shackelford, 1997; Cosmides \& Tooby, 1994a; Ellis, 1998; Tooby \& Cosmides, 1990a), and popular texts promoting this perspective have likewise flourished in recent years (i.e., Allman, 1994; Buss, 2000; Daly \& Wilson, 1999; Dennett, 1995; Gazzaniga, 1992; Pinker, 1994, 1997, 2002; R. Wright, 1994). Fueled in large part by the influence of sociobiology on the behavioral sciences over the past several decades, proponents of

Robert Lickliter, Department of Psychology, Florida International University; Hunter Honeycutt, Department of Psychology, Indiana University Bloomington.

The writing of this article was supported by National Institute of Mental Health Grants KO2 MH01210 and RO1 MH62225 awarded to Robert Lickliter. We thank Lorraine Bahrick, Richard Burian, Rebecca Markham, and David Moore for constructive comments on earlier versions of the article.

Correspondence concerning this article should be addressed to Robert Lickliter, Department of Psychology, Florida International University, Miami, Florida 33199. E-mail: licklite@ fiu.edu evolutionary psychology assert that applying insights from evolutionary theory to explanations of human behavior will stimulate more fruitful research programs and provide a powerful framework for discovering evolved psychological mechanisms thought to be forged by natural selection operating over thousands of generations (Bjorklund \& Pellegrini, 2000, 2002; Buss, 1989, 1991; Charlesworth, 1986; Cosmides, 1989; Crawford \& Krebs, 1998; Tooby \& Cosmides, 1990b).

Ideas gleaned from evolutionary biology have certainly influenced theory building in psychology (see Cairns, 1998; Cairns, Gariepy, \& Hood, 1990; Edelman, 1989; Gottlieb, 1991, 1992; Johnston, 1985; Sameroff, 1983). There is little doubt that the incorporation of evolutionary principles and perspectives into the psychological sciences can provide a useful heuristic framework for exploring the origins and nature of human psychological mechanisms (e.g., Deacon, 1997; Edelman \& Tononi, 2000; Stewart \& Cohen, 1997). Therefore, it seems to us worthwhile to examine the underlying and often implicit assumptions associated with contemporary attempts at forging an evolutionary psychology in light of current knowledge in developmental and evolutionary biology. Such an endeavor seems particularly important in that the assumptions of evolutionary psychology are often presented to psychologists having little background in or knowledge of genetics, embryology, developmental biology, or related disciplines contributing to modern evolutionary theory. Understandably, few psychologists have the time or interest to keep pace with the insights and discoveries regarding developmental and evolutionary processes emerging from the biological sciences over the past several decades. Even fewer have the background or training necessary to synthesize and integrate recent findings of genetics, embryology, developmental biology, and evolutionary theory. As a result, psychologists (and other professionals working in the behavioral sciences) can be easily swayed by those promoting the view that the development of an individual is best viewed as the unfolding or expression of a genetic program. 
Genetic programs do not, however, determine individual development. There exists a large and growing body of evidence that demonstrates that the development of any individual organism is the consequence of a unique web of interactions among the genes it carries; the complex, multidetermined molecular interactions within and across individual cells; and the nature and sequence of the physical, biological, and social environments through which it passes during development (Lewontin, 2000). These developmental dynamics must be incorporated into any plausible account of how an organism forms, grows, and changes over the course of ontogeny. Modern developmental science is based on the appreciation of this constant interplay between biology and experience (Cairns, Elder, \& Costello, 1996; Ford \& Lerner, 1992; Gottlieb, Wahlsten, \& Lickliter, 1998; Lerner, 1998; Oyama, 1985), yet such an appreciation remains lacking in most evolutionary accounts of human behavior.

In this article we explore how several of the fundamental assumptions underlying the conceptual framework promoted by current advocates of an evolutionary approach to psychological issues are seriously flawed in light of the knowledge provided by contemporary biology. Our specific objectives are to review recent conceptual advances in genetics, embryology, and developmental biology that have combined to provide a more epigenetic, contingent, and dynamic view of how organisms develop (e.g., Gilbert, 2000; Strohman, 1997). We explore how this shift in view challenges several of the underlying, often implicit assumptions typically made when evolutionary concepts are offered as explanations of human behavior. We conclude that the successful incorporation of evolutionary principles and theory into psychological science requires a developmental dynamics perspective. This perspective recognizes the central role of developmental processes in all biological and psychological explanations and rejects the predeterministic and instructionist frameworks common to contemporary evolutionary psychology and other gene-centered perspectives on human behavior. ${ }^{1}$

It is important to note that this article is not primarily intended as a direct or formal critique of evolutionary psychology, as there are several recent sources for such an approach (e.g., Buller \& Hardcastle, 2000; Caporael, 2001; Davies, 1999; de Jong \& Van der Steen, 1998; Lloyd, 1999; Lloyd \& Feldman, 2002; H. Rose \& Rose, 2000; Sterelny \& Griffiths, 1999). Rather, we are concerned here with reviewing recent conceptual advances in the biological sciences that have contributed to an ongoing transformation of contemporary developmental and evolutionary theory. In particular, we are concerned with how such advances challenge the credibility of views of human behavior that primarily concentrate on genetic factors and ignore or underplay the complex, highly coordinated system of regulatory dynamics known to be involved in developmental and evolutionary processes. We argue that a sound theory of human psychological mechanisms must be consistent with the central principles and empirical evidence of both developmental and evolutionary biology.

\section{Underlying Assumptions Common to Gene-Centered Frameworks of Phenotypic Development}

Like other frameworks or approaches in psychology, recent arguments for an evolutionary approach to psychology are based on a set of preconceptions and assumptions regarding the causes and nature of human behavior and development (Goldhaber, 1999; Lerner, 2002). As pointed out by Nisbett (1990), the preconceptions of evolutionary psychology are generally consistent with its predecessor fields of ethology and sociobiology and center around the assumption that basic aspects of an organism, including its morphology, physiology, and psychology, are best understood as the products of its genes. In other words, instructions for building organisms reside in the genes, and the genes are the vehicles by which these instructions are transmitted from one generation to the next. Individual ontogeny is thus understood as the process by which genotypic specification is translated or expressed into a given phenotype (see Crawford, 1998, for a recent example). This view has at its core a fundamental premise: that the bodily forms, physiological processes, and behavioral dispositions of organisms can be specified in advance of the individual organism's development (see Ingold, 2000, 2001; Lickliter \& Berry, 1990; Oyama, 1985, for further discussion). This specification is assumed to reside in evolved genetic programs that direct the course of individual development.

The notion that genes carry the instructions or programs for development is, of course, not original or unique to evolutionary psychology. During most of the 20th century, the biological sciences characterized the genes to be (a) the provider of intergenerational stability, (b) the factor responsible for phenotypic traits, and (c) the agent directing development of organisms (see Keller, 2000; Mayr, 1982; Portin, 1993). The foundational assumptions of most evolutionary approaches to psychological issues follow directly from these related tenets. However, as discussed below, none of these tenets have proven to be factual in light of the findings available from the biological sciences over the past several decades. New understanding of the complexity of developmental dynamics has undermined the conceptual adequacy of genes as the cause of development. Recent advances in genetics, embryology, and developmental biology have combined to provide a new appreciation of the magnitude of the gap between genetic activity and phenotypic outcomes (e.g., Gerhart \& Kirschner, 1997; Gilbert, 2000; Johnston \& Edwards, 2002; Lewontin, 2000; Pigliucci, 2001; Schlichting \& Pigliucci, 1998). It is now known that a wide array of nongenetic factors and conditions such as gravity, light, temperature, humidity, and population density can have powerful and significant influences on the way organisms develop (see Coen, 1999; Gilbert, 2001, for multiple examples).

One well-known example of this multidetermined developmental responsiveness is seen in sex determination in some reptiles and fish. The sex of all crocodilians, most turtles, and some lizards depends on the temperature at which they develop (see Gans \& Crews, 1992). Eggs incubated at one range of temperatures produce males, and eggs incubated at another range produce females. This temperature-dependent sex determination is a complex phe-

\footnotetext{
${ }^{1}$ Though a discussion of other dichotomous perspectives on human behavior and development, including behavior genetics and human behavioral ecology, is beyond the scope of this article, several of the underlying assumptions common in these fields parallel those of evolutionary psychology. These include the enduring notion that genetic and environmental influences on phenotypic development can be meaningfully separated or assessed independently. This assumption is not supported by the empirical findings of contemporary genetics, embryology, and developmental biology.
} 
notypic response that includes the functional sex of the individual, its primary and secondary sexual morphological characteristics, and the behavioral traits associated with being male or female. On a related note, certain species of coral reef fish are capable of sex reversal, which occurs on the basis of social group composition. These fish live in well-defined social groups in which there are only a few males. When males are removed from the social group, one of the group's females initiates a sex reversal, developing the behavior and gonadal physiology and anatomy of a male (Shapiro, 1981). These cases of experience-dependent changes in body, brain, and behavior provide a powerful illustration of how multiple factors (including genetic, hormonal, and environmental variables) provide resources for phenotypic development in nested levels of regulation during individual ontogeny.

As we discuss below, contemporary attempts to specify the nature of the relation between the genotype and the phenotype (e.g., Davidson, 2001; Nijhout, 2001; Schlichting \& Pigliucci, 1998) provide a radically different view from that assumed by evolutionary psychology and other gene-centered views of human behavior. This dynamic, contingent, and bidirectional account of gene action is not yet widely acknowledged or discussed within the psychological sciences (but see Gottlieb, 1997, 1998, 2002; Johnston \& Edwards, 2002; Moore, 2002) but clearly has significant implications for the types of causal frameworks that guide research within the psychological sciences. In particular, this developmental dynamics approach effectively undermines the notions that genes can be primarily responsible for the production of phenotypes and that genetic and environmental determinants of development can be effectively separated or partitioned.

\section{Misrepresenting Genes as the Program for Development}

The notion of a centralized program for development that resides in the genome and is primarily responsible for an individual organism's traits and characteristics remains a foundational premise within evolutionary psychology (see Crawford \& Krebs, 1998, for recent examples). This premise is based on the underlying assumptions that phylogenetic information is somehow encoded in the genes and that in the course of development this information unfolds by way of (a) predetermined maturation or (b) activation by some (usually unspecified) environmental input. This view is particularly prevalent in recent attempts to apply evolutionary theory to psychological issues (see Barkow, Cosmides, \& Tooby, 1992; Buss, 1995; Crawford \& Krebs, 1998; Gaulin \& McBurney, 2002; Tooby \& Cosmides, 1989) and was clearly portrayed by Tooby and Cosmides (1990a):

Every coherent psychological theory has at its foundation innate mechanisms or procedures, either explicitly recognized or tacitly entailed. To say that such procedures are innate means they are specified in the organism's genetic endowment, that is, in how genetically based programs regulate the mechanisms governing development. This genetically specified, innate foundation of the psyche is the product of evolutionary process, and is the means by which the evolutionary process organizes the psychology of the animal over generations. (p. 22)

This explicitly preformationistic view virtually ignores the role of developmental processes in the realization of phenotypic characters or traits. It assumes that development is internally determined, set on course at conception and specified by genetic programs designed and selected over evolutionary time. The application of such approaches to human behavior and development draws much of its force from the belief that natural selection, acting in previous generations, delivers a set of genotypes to the current generation, out of which the "black box" of maturation constructs phenotypes.

This view is reminiscent of the writings of the classical ethologists (e.g., Lorenz, 1965) and sociobiologists (e.g., Wilson, 1975) in that it assumes that many phenotypic outcomes (including behavior) can somehow be prespecified, being part of the innate constitution of the organism and arising relatively independently of the organism's specific physical, biological, and social interactions during development. For example, Lorenz's (1965) view of instinct was based on a strong distinction between those elements of behavior that are specified by the genes and those that arise in the course of individual experience. Tooby and Cosmides (1990b) offered a contemporary version of this perspective:

The individual organism, fixed at conception with a given genetic endowment regulating its developmental programs, encounters its specific ontogenetic environment, which it processes as a set of inputs to these developmental programs. In other words, the organism blindly executes the programs it inherits, and the ontogenetic conditions it encounters serve as parametric inputs to these programs. ( $p$ 388)

Other evolutionary psychologists likewise have argued for a hard distinction between genetic and environmental influences on behavior. Buss (1999) proposed that "human behavior cannot occur without two ingredients: (a) evolved adaptations and (b) environmental input that triggers the development and activation of these adaptations" (p. 18). Thus, even when the influence of the environment or the organism's experience is acknowledged, it is viewed as secondary to the role of genetic factors (see also Buss, 1995; Nisbett, 1990). In most cases, the role of the environment is typically reduced to that of an "activator" or "trigger" of instructions, thought to have been present in the organism since conception. For example, Gaulin and McBurney (2002) argued that "any attempt to explain why experiences have the effects they do automatically admits that the experience acts on something that has an inherent nature to respond in particular ways" (p. 394).

Although most proponents of evolutionary psychology point out that they are "interactionists" and have moved beyond outdated notions of genetic determinism, their version of interactionism reflects a deep-seated ontological separation between causal components that represent nature (genes) and those that represent nurture (all else). That is, although all phenotypes are acknowledged to result from the interplay between genes and environments, this interplay is decidedly one sided. Genes are characterized as playing the determinative role in the form and nature of phenotypic characteristics, and nongenetic factors are thought to simply activate or trigger the various predetermined developmental instructions presumed to be encoded in the organism's genome. From this view, genes are seen to allow environmental influences on phenotypic development (see Cosmides \& Tooby, 1997b).

Researchers who appeal to these types of interactionist explanations for human behavior and development embrace some form of the dichotomous idea that individual development is determined by either (a) phylogenic factors that operated on the ancestors of the individual and that deliver (via the genes) specifications for 
phenotypic outcome or (b) ontogenetic events that occur during the life of the individual and that facilitate or interfere with the unfolding or expression of these specifications (Chisholm, 1999; Plotkin, 1994). This habit of thinking about phylogeny and ontogeny as alternative means by which information is made available to the developing individual has a long history in both biology (Haeckel, 1879; Weismann, 1889) and psychology (G. S. Hall, 1904; Spencer, 1855) and was promoted by a number of prominent evolutionary theorists in the last century (e.g., Dobzhansky, 1951; Jacob, 1982; Mayr, 1961). This perspective and its basic assumption was well illustrated by the evolutionary biologist Ernst Mayr (1982):

Organisms, in contrast to inanimate objects, have two different sets of causes because organisms have a genetic program. Proximate causes have to do with decoding of the program of a given individual; evolutionary causes have to do with the changes of genetic programs through time, and with the reasons for these changes. (p. 68)

Like Mayr, most evolutionary psychologists argue for the heuristic value of the conceptual decoupling of proximate (ontogenetic) and evolutionary (phylogenetic) levels of explanation (see Buss, 1999; Crawford, 1998; Daly \& Wilson, 1978; Gaulin \& McBurney, 2002). Furthermore, most assume that evolutionary factors are somehow ontologically prior to and more fundamental than proximate factors in directing phenotypic outcomes. This viewpoint is evident in nearly all current evolutionary accounts of human behavior and development (but see Bjorklund \& Pellegrini, 2002, for a well-developed exception). Lickliter and Berry (1990) termed this dichotomous conceptual framework the phylogeny fallacy. The phylogeny fallacy is based on the assumptions (a) that phylogeny and ontogeny are alternative processes by which information is made available to the developing individual and (b) that specification for an organism's phenotype can exist independently and in advance of its real-time developmental processes (see also Ingold, 2001; Oyama, 1985). This framework is based (often implicitly) on a strong form of genetic predeterminism and ignores or downplays the fundamental role of developmental processes in the realization of all phenotypic characters or traits.

The assumption of genetic predeterminism (and the trivialization of developmental processes) is at the core of perhaps the most influential idea concerning the nature of human behavior promoted by contemporary evolutionary psychology - that learning and reasoning depend on a battery of evolved, innate mental "modules" that structure information processing in different cognitive domains (Barkow et al., 1992; Caruthers \& Chamberlain, 2000; Cummins \& Allen, 1998; Hirschfeld \& Gelman, 1994; Samuels, 1998). A brief examination of several assumptions associated with the notion of mental modules reveals the extent to which the premise of prespecification pervades the underlying conceptual framework of current evolutionary psychology.

\section{Modularity: The Phylogeny Fallacy Applied to the Mind}

Initially fueled by the writings of nativists such as Chomsky (1980), Fodor (1983), and Gardner (1984), among others, the idea that innate rules of perception, cognition, and behavior can be coded in genes and biologically inherited is now common currency in several of psychology's subdisciplines, including developmental psychology (e.g., Geary \& Bjorklund, 2000; Scholl \& Leslie,
1999; Spelke \& Newport, 1998) and cognitive psychology (e.g., Coltheart, 1999; Gerrans, 2002; Gigerenzer \& Hug, 1992; Shepard, 1997). In its strongest form, this view assumes that a number of elementary perceptual and cognitive processes, as well as some overall executive functions and aspects of knowledge, are preformed and simply triggered by features of experience (Plotkin, 1994; Spelke, 1994; Spelke, Brienlinger, Macombre, \& Jacobson, 1992). For example, the cognitive psychologist Roger Shepard (1997) has argued that

the still widely held version of empiricism that insists that any knowledge which an individual possesses about the world can only have come through the individual's own sensory interactions with the world is wholly untenable. The remarkable behavioral capabilities of animals ... depend on a deep, if implicit wisdom about the world that is our genetic legacy from countless aeons of ancestral interaction with the world. (p. 24)

As reviewed by Richardson (1998), this idea that innate processes somehow form the basic architecture of human cognition has become widespread in the psychological sciences over the past decade. Theories abound in which cognitive abilities are viewed as a relatively fixed phenotypic character, designed by natural selection and innately specified in the genes (see Cosmides \& Tooby, 1994b; Plotkin, 1998; Spelke \& Newport, 1998; Sperber, 1996). Pinker (1997), among others, has promoted a strong version of this view, proposing that "the mind is organized into modules or mental organs, each with a specialized design that makes it an expert in one arena of interaction with the world. The modules' basic logic is specified by our genetic program" (p. 21).

Proponents of this view have suggested that there are likely hundreds if not thousands of such modules, each individually created and set in place hundreds of thousands or even millions of years ago, because each solved an adaptive problem faced by our ancestors during the Pleistocene (Tooby \& Cosmides, 1992, 1995). Mental modules have been proposed for a wide range of perceptual, cognitive, and behavioral functioning, including the processing and production of syntax (Pinker, 1994), the assessment of the physical attractiveness of potential mates (Symons, 1995), the judgment of infidelity (Buss, 2000), theories of the mental states of others (Baron-Cohen, 1995), and incest avoidance (Tooby \& Cosmides, 1992) to name but a few. These modules or mental organs are seen as a primary source for the intergenerational stability of human behavior and, in their totality, are thought to represent underlying human nature (Buss, 1995; Cosmides \& Tooby, 1997b D. Jones, 1999).

Mental modules are thought to have a predetermined structure and to come equipped with certain innate knowledge and an innate set of procedures for applying that knowledge to its special domain (Cosmides \& Tooby, 1994a; Pinker, 1997). For example, Cosmides and Tooby (1997b) argued that human cognition is directed by genes coding for psychological mechanisms that organize an individual's experience into adaptively meaningful schemas or frames. Similarly, Crawford (1998) argued for the existence of innate learning mechanisms that organize experience into adaptively meaningful schemata. These schemata represent a form of informational encapsulation and are thought to be triggered or activated by appropriate environmental problems. They are proposed to focus attention, organize perception and memory, and elicit domain-specific procedural knowledge in such a way as to 
support adaptive inferences, judgments, and choices. Bereczkei (2000) captured the essence of this view, claiming that "genes guide mental development, and as a consequence, the human brain is equipped with certain psychological processes (perceptual filters, learning rules, cognitive maps, etc.) that organize experience in an evolutionary meaningful way" (p. 183).

Use of the modularity concept in contemporary evolutionary psychology is based in large part on the phylogeny fallacy, in that a given mental module is thought to contain evolved, innate features that are informationally encapsulated and develop in the absence of any explicit instruction or direct experience in the problem domain for which the module is specialized (see Buller \& Hardcastle, 2000, for further discussion). In other words, modules are assumed to preexist individual development and to lie dormant somewhere in the structure of the organism, awaiting activation by some (usually unspecified) experiential events.

However, modularity of psychological functioning (if any) is always a matter of individual development, emerging out of the ongoing transaction between a structured organism and its structured physical, biological, and social environments. It is the entire developmental system, including the specific features of the environment an individual organism actually encounters and interacts with (and not the environments of distant ancestors) that brings about any modularity of cognitive function (Richardson, 1998). Recent advances in genetics, embryology, and developmental biology combine to underscore that it is biologically untenable to view mental modules as preformed phenotypic units or traits, somehow specified in a genome assumed to be the sole hereditary unit capable of directing developmental events.

\section{The Misrepresentation of Genes as Stable and Privileged Units of Heredity}

Viewing genes as the sole provider of intergenerational stability has been a cornerstone of evolutionary theorizing for much of the past century (see Mayr, 1982). This assumption rests on the common suppositions that genes are the stable, encapsulated units of heredity that underlie an organism's phenotype and are transferred relatively unaltered through generations. The sociobiologist Richard Dawkins (1976) gave strong voice to this perspective several decades ago:

We, the individual survival machines in the world, can expect to live a few more decades. But the genes in the world have an expectation of life which must not be measured in decades but in thousands and millions of years.... When we have served our purpose we are cast aside. But genes are denizens of geological time; genes are forever. (p. 36)

Proponents of evolutionary psychology have continued to implicitly or explicitly embrace this view of the genes, talking about them as if they have persisted in an immutable form, impenetrable to outside influence, for millions of years (e.g., Buss, 1995; Tooby \& Cosmides, 1990a). For example, Tooby and Cosmides (1990b) argued that

present selection pressures or environmentally imposed tasks are causally irrelevant to the present design of organisms and have no role in explaining them. For a Darwinian, the explanation for our present system of adaptations lies completely in the past, starting one gener- ation ago, and extending back across phylogenetic time to include the history of selection that constructed those designs. (p. 378)

This perspective requires that some form of transgenerational information prespecifies the organism's various phenotypic outcomes, leading most evolutionary psychologists to assume that underlying all individual traits or characters is a heredity unit, the gene, so inherently stable and immutable that it alone can account for the reliability by which phenotypic traits are transmitted across generations (e.g., Crawford, 1998).

However, it is no longer possible to speak of genes as constant and immutable, operating outside the reciprocally interactive developmental system (Coen, 1999; Gottlieb, 1992, 1998; Jablonka, 2001; Lewontin, 1991; Moore, 2002; Oyama, Griffiths, \& Gray, 2001; Robert, Hall, \& Olson, 2001; Sterelny \& Griffiths, 1999). Converging evidence from genetics (Davidson, 1986, 2001; Jenuwein \& Allis, 2001; Pritchard, 1986), embryology (Edelman, 1988; Muller \& Steicher, 1989; Nijhout, 1999), and developmental biology (Curran, Smeyne, Robertson, Vendrell, \& Morgan, 1994; Gilbert, 2001; Gilbert, Opitz, \& Raff, 1996) has demonstrated that gene activity (or inactivity) is determined by multiple influences from other levels of the developmental system, including molecular, cellular, physiological, and behavioral components (see also Gottlieb, 2001; Johnston \& Edwards, 2002; Oyama, 1985).

Contrary to the well-known central dogma of molecular biology (see Crick, 1970), which holds that information flows unidirectionally from the genes to the structure of proteins (and not in the reverse), a substantial body of evidence now exists showing that external influences on gene activity are normally occurring events in a large variety of organisms (reviewed in Gottlieb, 1998). Converging findings from genetics and molecular biology have demonstrated that a host of internal and external signals can stimulate or inhibit gene expression, including such nonobvious factors as the light-dark cycle (Hegarty, Jonassent, \& Bittman, 1990) and tactile stimulation (Mack \& Mack, 1992). This pattern of contingency is now recognized as part of the normal process of development within embryology and developmental biology, and there is a growing body of literature demonstrating how epigenetic factors, including internal neural and hormonal events and external sensory events, activate or inhibit gene expression during individual development (see Davidson, 1986, 2001; Gilbert, 2000; Holliday, 1990; Pritchard, 1986).

For example, the fibular crest is a leg bone that connects the tibia to the fibula in birds. It allows the force of the iliofibularis muscle to pull directly from the femur to the tibia. This direct connection allows the reduction in size of the femur bone seen in most birds and is considered a universal feature of the bird hind limb. However, when the developing chick embryo is prevented from moving within its egg during prenatal development, this bone fails to develop. In other words, embryonic movements appear to induce the development of bone in the chick embryo (see Muller $\&$ Steicher, 1989). This complex of regulatory interactions of genes, gene products, and external influences is a cogent example of a core feature of the notion of developmental dynamics-what a given gene does in terms of what it provides the developmental process depends on its context. Simply put, genetic and nongenetic factors cannot be meaningfully partitioned when accounting for developmental outcomes. The pathway from genes to phenotypic traits is far more complex, nested, and contingent than has been 
acknowledged by the paradigms of contemporary evolutionary psychology, behavioral genetics, and other dichotomous approaches to human development and behavior.

\section{Taking Development Seriously: Epigenetic Regulation of Phenotypic Evolution}

Initial efforts toward a reformulation of the nature and role of gene dynamics was provided by a small group of evolutionary geneticists working in the first half of the last century who realized that genes were potentially much more sensitive to context than had previously been proposed and that changes in evolution likely involve alterations in development (e.g., Goldschmidt, 1940, 1950; Schmalhausen, 1949; Waddington, 1940, 1957; S. Wright, 1968). For example, Goldschmidt (1951) criticized the encapsulated gene concept on grounds that chromosomes are better characterized as response systems with complex internal interactions. From his view, evolution involved heritable changes in development, and genes were only abstractions, reflecting the various interactions of parts of chromosomes when they were in one stable configuration (as opposed to another). Goldschmidt (1951) went on to propose that some form of organizational control at a higher level than the genes must be involved in phenotypic evolution. Although the specific details of his view have not held up to current knowledge, his early efforts to appreciate the developmental dynamics of phenotypic change set the stage for more recent conceptual and empirical efforts aimed at a fuller understanding of the relationship between genetics, development, and evolution (e.g., Burian, 1986, 2000; Gilbert et al., 1996; Gottlieb, 1992; Jablonka \& Lamb, 1995; Raff \& Kaufman, 1983).

It is now known that the expression of genes is routinely affected or modified, not only by other genes, but also by the local cellular as well as the extracellular environment of the developing organism (reviewed in Davidson, 2001; Gerhart \& Kirschner, 1997; Gilbert, 2000; Schlichting \& Pigliucci, 1998). Hundreds of published reports studying dozens of experimental organisms have demonstrated that gene activity is influenced by a complex network of interactions involving cell cytoplasmic factors, hormones, and even sensory stimulation early in development (so-called immediate-early gene expression; see Clayton, 2000; Hughes \& Dragunow, 1995; Mello, Vicario, \& Clayton, 1992; Rampon et al., 2000; Tischmeyer \& Grimm, 1999). Genes cannot be characterized as occupying a privileged position in the development of an organism, as they are themselves participants in the developmental process, which includes influences and interactions taking place at many hierarchically arranged levels, including nucleuscytoplasm, cell-cell, cell-tissue, and organism-organism (Gottlieb, 1991, 1992; Sole \& Goodwin, 2001).

This developmental view of gene action, derived from converging research in molecular genetics, embryology, developmental biology, and psychobiology (e.g., Coen, 1999; Gilbert, 1994; Gottlieb, 1997; P. A. Jones \& Takai, 2001; Moss, 2001; NeumannHeld, 1998), provides a compelling alternative to the long-standing idea of genes as encapsulated units of heredity, insensitive to outside influences. The notion of the encapsulated genome can be traced back to the work of August Weismann (1889), who argued for a complete separation of the "germ plasm" from its expression in the phenotype (the so-called Weismann barrier; see Johnston, 1995). Weismann claimed that only changes in the germ line could contribute to evolutionary changes and that these changes were distinct from what happens to the organism during its lifetime. The adoption of this view in the first half of the 20th century effectively divorced issues of development from those of evolution (see Mayr, 1982). Mounting evidence suggests that this hard-line view is incorrect. Mae-Won Ho (1984) captured the core of this shift in thinking nearly 20 years ago:

\begin{abstract}
The genomic content of every organism is for the first time susceptible to being read base by base from beginning to end. Yet the first glimmerings have already yielded major surprises. Forever exorcised from our collective consciousness is any remaining illusion of development as a genetic program involving the readout of the DNA "master" tape by the cellular "slave" machinery. On the contrary, it is the cellular machinery which imposes control over the genes.... The classical view of an ultraconservative genome-the unmoved mover of development-is completely turned around. Not only is there no master tape to be read out automatically, but the "tape" itself can get variously chopped, rearranged, transposed, and amplified in different cells at different times. (p. 285)
\end{abstract}

The picture of genetic influences assumed and promoted by evolutionary psychology is in stark contrast to such an epigenetic view of gene action. In keeping with the basic theme of the central dogma, evolutionary views of human behavior and development typically assume that genetic activity and its effects on development can be regulated only by the genes themselves. Environmental or experiential factors are not seen as crucial features of individual development because genes are assumed to be buffered from extragenetic influences, thereby allowing them to contain an enduring program or plan for the specification of phenotypic traits and characters. For example, Tooby and Cosmides (1990a) have argued that "complex adaptations are constructed by developmental programs, which in turn are regulated by genetic programs. These genetic programs comprise hundreds or thousands of genes, operating within a fixed developmental background created by the rest of the genome" (p. 44). In a recent evolutionary psychology text, Gaulin and McBurney (2002) proposed "that instructions flow outward from the gene, never inward, is central to both modern genetics and to our picture of evolution" (p. 50).

Although this scenario of an insulated or encapsulated genome and the implicit assumption of a unidirectional chain of processes leading from the gene to the appearance of a phenotypic trait have not been supported by several decades of evidence from contemporary biology, many psychologists remain unaware that activation or expression of genes is regularly subject to influences from higher levels in the organism system during the course of development. This is unfortunate, as the psychological sciences have much to offer in the forging of theories of the epigenetic regulation of development and evolution (see Gottlieb, 1991, 1998; Johnston \& Edwards, 2002; Lickliter \& Ness, 1990, for examples).

\section{The Role of Extragenetic Inheritance}

The widespread conception of genes as the sole source of transgenerational stability and inheritance has been further weakened in recent years by a growing appreciation of the importance of extragenetic factors involved in inheritance and phenotypic stability across generations (see Ferguson-Smith \& Surani, 2001; Gilbert, 1991; Jablonka \& Lamb, 1995). These extragenetic factors 
include cytoplasmic chemical gradients, basal bodies and microtubule organizing centers, DNA methylation patterns, membranes, and organelles. As cell and molecular biologists know, gene expression depends on a host of epigenetic phenomena that can persist across generations. Over the past several years, for example, researchers have shown that gene activity is influenced by the proteins that package the DNA into chromatin (the protein-DNA complex involved in fitting the genome into the cell nucleus), chromatin-modifying enzymes (which can also modify the DNA itself), and maternal RNA (P. A. Jones \& Takai, 2001; Reik, Dean, $\&$ Walter, 2001). Chromatin-modifying enzymes are known to influence the many changes through which the fertilized egg cell transforms into a complex organism during embryonic development, and in later life these enzymes also enable cells to respond to hormones, growth factors, and other regulatory molecules. Changes in these and other extragenetic elements (independent of changes in DNA) can cause heritable variation that appears in all the cells that descend from a given egg cell. ${ }^{2}$ In other words, epigenetic factors can control patterns of gene expression that are then passed on to successive generations. These elements and mechanisms have been termed epigenetic inheritance systems (Jablonka \& Lamb, 1995), and their presence and activity argues against the entrenched idea that stable, encapsulated genes are all an organism inherits from its ancestors in previous generations.

In mammals, for whom the embryo develops within the body of the female, these epigenetic factors include noncytoplasmic maternal effects, including uterine effects (Vom Saal \& Dhar, 1992). Several studies have demonstrated that when a female rodent embryo develops in a uterine environment in which most adjoining embryos are male, their prenatal exposure to the relatively high level of testosterone produced by their male siblings results in later maturation and the display of more aggressive and territorial behavior than that displayed by other females (Clark \& Galef, 1995; Clark, Karpiuk, \& Galef, 1993). These testosterone-exposed females go on to produce litters in which the proportion of male offspring is greater than the normal 1:1 sex ratio, and as a result their daughters also develop in a testosterone-rich uterine environment, demonstrating the significant role of extragenetic factors in the transgenerational stability of phenotypic traits (see Jablonka, 2001 , for other similar examples of nongenetic phenotypic transmission). This insight, that changes in either genetic or extragenetic influences in development can lead to enduring transgenerational change in the phenotype, has received little attention within the psychological sciences (but see Gottlieb, 1992, 2002; Johnston \& Gottlieb, 1990) but clearly calls into question the completeness of gene-centered views of human behavior and development.

Such findings have led to several proposed reconceptualizations of inheritance and how genes should be characterized (e.g., Beurton, Falk, \& Rheinberger, 2000; Gilbert, 2000; Griffiths \& Neumann-Held, 1999; Neumann-Held, 1998; Sarkar, 1998) and have even spurred discussions as to whether retaining the geneas-independent-unit concept is heuristically useful (Falk, 2000; Kitcher, 1992). Regardless of one's perspective on the units of inheritance controversy, the foregoing discussion strongly suggests that (a) gene functioning is always a matter of contingency and (b) the development of phenotypes emerges not from genetic programs but from the structured, bidirectional dynamics of a developmental system. Perhaps the most salient consequence of these insights is the growing recognition that development matters.
That is, phenotypic outcomes cannot be predetermined or programmed, they emerge from dynamic processes that make up the complex interplay of the various factors involved in a developmental system. These include the genes and a host of extragenetic factors operating over the course of individual ontogeny. In a self-regulating multilevel system such as an organism, control of development is not prescribed in the genes but is exerted by the regulatory dynamics of the gene-in-a-cell-in-an-organism-in-anenvironment system (see B. K. Hall, 1999; Mahner \& Bunge, 1997; Oyama et al., 2001; Richardson, 1998). This distributed and contingent network of control is at the heart of the developmental dynamics approach and challenges the long-standing notion that one can meaningfully separate or partition genetic and environmental influences on human behavior and development (see Johnston, 1987). It likewise presents a significant challenge to developmentally naive frameworks that continue to regard genes as the source of ultimate control for phenotypic expression (see Gottlieb, 1995; Moore, 2002; Rollo, 1995, for further discussion). To regard the phenotypic traits of an organism as simply the "manifestation" or "expression" of its genotype, to assert that genes can make people behave in particular ways in particular circumstances (as argued by a number of evolutionary psychologists), ignores the known principles of both developmental biology and psychology (Gilbert, 2000; Gottlieb et al., 1998; Mahner \& Bunge, 1997; Michel \& Moore, 1995). Contemporary life sciences indicate that there are many gene-dependent processes but no gene-directed ones.

\section{The Distributed Control of Developmental Dynamics}

Developmental biology and developmental psychology have provided a wealth of examples over the past several decades demonstrating that phenotypic traits, be they morphological, physiological, or psychological, are always the products of developmental dynamics, the complex system of regulatory processes that operates simultaneously across multiple levels of the organismenvironment system (Coen, 1999; Dover, 2000; Gerhart \& Kirschner, 1997; Gottlieb, 1991; Rollo, 1995; Thelen \& Smith, 1998). As discussed earlier, factors associated with these regulatory dynamics include genes, but they also include enzymes, hormones, temperature, diet, photoperiod, and population density, to name but a few (Gilbert, 2001; Johnston \& Gottlieb, 1990).

For example, hemispheric lateralization or specialization in birds and mammals has historically been attributed solely to genetic factors (see Collins, 1977; Provins, 1997, for reviews). A

\footnotetext{
${ }^{2}$ The details of epigenetic inheritance have received increasing research attention in recent years (see Pennisi, 2001). An intriguing example is the phenomenon of genetic imprinting, in which genes passed on by each parent are somehow permanently marked so that the expression of the maternal and paternal genes differ in their offspring. A well-known example of the consequences of genetic imprinting are the phenotypic differences between the hybrids of a horse and a donkey. A mare bred to a male donkey produces a mule, but a stallion bred to a female donkey results in a hinny, which has noticeably shorter ears, a thicker mane, and stronger legs than its mule counterpart. These types of so-called parent-of-origin effects are due to epigenetic factors, including patterns of DNA methylation, which are known to affect gene activity and suppression across generations.
} 
number of studies have, however, demonstrated that the asymmetrical sensory stimulation that results from the relationship between the developing organism and the structure of its prenatal environment serves to induce the lateralization of behavior (Rodgers, 1995). As a case in point, the direction of lateralization in the avian forebrain has been found to be determined, at least in part, by the asymmetrical prenatal sensory experience of the developing embryo. In the later stages of prenatal development, the avian embryo is oriented in the egg such that its left eye and left ear are occluded by the body and yolk sac, whereas the right eye is exposed to light passing through the egg shell and the right ear is exposed to sound passing through the egg shell. The differential prenatal visual experience resulting from this postural orientation prior to hatching appears to facilitate the development of the left hemisphere of the brain in advance of the right and to significantly influence the direction of hemispheric specialization for a variety of postnatal behaviors, including visual discrimination, spatial orientation, and various motor asymmetries (Casey \& Lickliter, 1998; Casey \& Martino, 2000; Rodgers, 1982, 1986; Zappia \& Rodgers, 1983). Similar patterns of prenatal influence on postnatal cerebral dominance have also been proposed for mammals, including humans (Previc, 1991; Turkewitz, 1988, 1991). Converging evidence indicates that hemispheric asymmetries are the product of the complex interplay between a number of organismic and environmental factors (see also Denenberg, 1981) and cannot be vaguely explained as the product of programs, specifications, or precoded instructions.

Indeed, a wealth of empirical evidence from developmental biology and psychology suggests that there are no programs or blueprints for phenotypes, only dynamic and contingent processes that involve a complex array of endogenous and exogenous features that give rise to morphology, physiology, and behavior (see Gottlieb, 1997; Keller, 2000; Lewontin, 2000; Oyama, 1985, 2000; S. Rose, 1998, for recent discussions). This general principle of distributed and contingent control, evident throughout contemporary embryology, developmental biology, and developmental psychology (see Gilbert, 2000; Gottlieb, 1991; Lickliter, 2000; Thelen, Schoener, Scheier, \& Smith, 2001), remains noticeably absent from the conceptual frameworks of contemporary evolutionary psychology.

\section{Development and Evolution: Recent Steps Toward a Modern Synthesis}

In contrast to the instructionist themes of contemporary evolutionary psychology, a consistent theme in contemporary evolutionary biology is that the processes and mechanisms of development cannot be overlooked or underestimated if fuller insight into both individual development and evolution is to be gained (i.e., Gilbert et al., 1996; Goodwin, Holder, \& Wylie, 1983; Gottlieb, 1992; B. K. Hall, 1999; Ho \& Fox, 1988; Johnston \& Gottlieb, 1990; Oyama, 1985, 2000; Raff, 1996; Raff \& Kaufman, 1983). The increasing appreciation of the importance of developmental dynamics within evolutionary biology has resulted in the growth of several new interdisciplinary fields, including ecological developmental biology (eco-devo; see Gilbert, 2001) and evolutionary developmental biology (evo-devo; see Burian, 2000; Gilbert \& Burian, in press; B. K. Hall, 1999; Raff, 2000). These interdisciplinary approaches are attempting to integrate developmental, eco- logical, evolutionary, and genetic studies to account for how changes in development bring about evolutionary changes and how the mechanisms of development can guide and constrain evolution. This integrative effort has involved moving beyond the notion of genes as the primary cause of the production of phenotypes and exploring the broader principles, resources, and constraints that direct development. From the perspectives of eco-devo and evo-devo, the environment cannot be viewed as merely a permissive or triggering factor in development; rather, it is a critical feature of developmental biology. For example, the environment of development has been shown to determine sexual phenotype in some species of reptiles and fish, induce specific morphological changes that allow individuals to escape predation in several amphibian species, and bring on caste determination in a number of species of insects (Gilbert, 2001). These types of discoveries have fostered several conceptual reformulations regarding the nature of the relationship between development and evolution in recent years, including the role of homology in macroevolutionary theory (B. K. Hall, 1994; Muller \& Wagner, 1996), the role of developmental constraint and plasticity in microevolutionary processes (Maynard Smith et al., 1985; Riedl, 1978; Wagner \& Altenberg, 1996), and how best to characterize the role of natural selection in the explanation of innovations and evolutionary change (Depew \& Weber, 1995; Sober, 1993). ${ }^{3}$ These conceptual efforts have been effectively ignored by evolutionary psychology, where the idea that all of biology and psychology can be explained by past events of differential reproduction and selection continues to hold strong.

For example, explanations of how innate psychological mechanisms or mental modules could be generated and organized almost always invoke the creative power of natural selection (see Pinker, 1997). Cosmides and Tooby (1997a) have proposed that "natural selection is the only component of the evolutionary process that can introduce complex functional organization into a species' phenotype" (p. 133). Buss, Haselton, Shackelford, Bleske, and Wakefield (1998) likewise claimed that "natural selection is the only known causal process capable of producing complex functional organic mechanisms" (p. 533). Gaulin and McBurney (2002) argued that "natural selection cannot design behavior directly. It designs psychological organs that produce adaptive behavior" (p. 26). However, explaining ontogenetic processes or outcomes by appealing to the creative or designing role of natural selection is inherently misleading because natural selection is not a creative force capable of producing phenotypic variation. It has long been appreciated, even by Darwin, that the notion of natural selection presupposes phenotypic variation and does not account

\footnotetext{
${ }^{3}$ The emerging evo-devo field has provided a number of useful examples of the importance of developmental dynamics to understanding both development and evolution. For example, a major theme within evo-devo involves asking how changes in development lead to the production of novel morphological structures (e.g., how birds formed feathers, how turtles got their shells, how elephants got their trunks). The emergence of morphological innovations appears to depend, at least in large part, on the epigenetic dynamics of the involved developmental pathways (Newman \& Muller, 2000). For example, recent evidence suggests that relatively minor changes in Hox gene-expression patterns during development can help explain the loss of snake forelimbs, the formation of limbs from fins, and the number of vertebrae in vertebrates (see Cohen \& Tickle, 1999).
} 
for the origin of such variation (see Endler, 1986; Gould, 2002; Johnston \& Gottlieb, 1990; Mivart, 1871). The role of natural selection is inherently limited, in that it can only influence the distribution of existing phenotypes in a population by reducing the number of unsuccessful phenotypes. Contrary to the claims of evolutionary psychologists, it cannot account for how these phenotypes are generated.

In recent years, a number of biologists, psychologists, and philosophers have reemphasized the insight that natural selection has no formative or creative power but is instead best viewed primarily as a filter for unsuccessful phenotypes generated by developmental processes (Brandon, 1996; Gilbert et al., 1996; Johnston \& Gottlieb, 1990). Gottlieb (1998) provided a useful summary of this view: "Natural selection serves as a filter and preserves reproductively successful phenotypes. These successful phenotypes are products of individual development and thus are a consequence of the adaptability of the organism to its developmental conditions" (p. 796). In other words, variations in morphologies, physiologies, and behaviors resulting from modification in developmental processes place their possessors in different ecological relationships with their environments. If these phenotypic variations provide slight advantages in survival and reproduction, then competitors without the novel phenotype will eventually decrease in frequency in the population. The novelty-generating aspects of evolution are thus primarily the result of the developmental dynamics of living organisms, situated and competing in specific ecological contexts (Oyama et al., 2001). Van Valen (1973) succinctly highlighted this perspective 30 years ago by proposing that evolution is best considered "the control of development by ecology" (p. 8).

Although the nature and importance of natural selection in evolution is a matter of continuing dispute (Barton \& Partridge, 2000; Gould, 2002; Sober, 2000; Williams, 1992), a reconceptualization of the role of natural selection in evolutionary change is becoming more evident within the fields of embryology and developmental biology (see Gilbert, 2000, for recent examples). Research efforts concerned with the formation of new phenotypes through changes in the spatial and temporal expression of developmental regulatory genes (Cohen \& Tickle, 1999) and efforts concerned with the nature of normally occurring environmental influences on gene activity (Meaney et al., 1996; Mello et al., 1992) have provided converging support for the view that variations in phenotypes are made possible by changes in development (in addition to such recognized factors as genetic mutation, genetic recombination, and genetic drift). ${ }^{4}$ These variations are then subsequently filtered by natural selection (Gottlieb, 2002; Strohman, 1997). As recently pointed out by Burian (2000), evolution is more likely to be understood in terms of changes in developmental processes rather than simply in terms of changes in gene frequencies or gene action.

The core of this idea is not new. More than 60 years ago the embryologist Gavin deBeer (1940) argued that evolutionary change in the phenotype can come about only by changes in development. However, for deBeer and other theorists working on the relation between development and evolution during the first half of the last century (e.g., Goldschmidt, 1951; Waddington, 1948), alterations in development that were proposed to initiate evolutionary changes were believed to ultimately result from genetic changes (see Gottlieb, 1992, for further discussion). For example, the Russian geneticist Schmalhausen (1949) believed that developmental interactions provided the regulatory control for much of phenotypic development. However, from his viewpoint, variations in these interactions and their susceptibility to genetic change was thought to provide the genetic raw material on which natural selection could act (see B. K. Hall, 1999).

More recently, Gottlieb $(1987,1992,2002)$ argued that genetic changes are often not the initiator but instead the consequence of changes in development. In particular, shifts in behavior brought about both by changes in the environment and the resulting changes in the activity of the organism are seen to lead to new structural and functional relationships among elements of the developmental system within and across generations, which ultimately can lead to variations in anatomy, morphology, or physiology that are independent of enduring changes in gene frequencies. This scenario highlights the heuristic value of replacing the notion of genetic control of development with an appreciation of developmental dynamics, thereby widening the scientific sense of developmental and evolutionary resources and promoting the empirical investigation of their application to phenotypic evolution (see also Pigliucci, 2001; Schlichting \& Pigliucci, 1998).

Johnston and Gottlieb (1990) provided several examples of how new phenotypes may arise due to an enduring change in the patterns of organism-environment interaction rather than simply by genetic change. As a case in point, they described a scenario in which a population of rodents whose normal diet consists of soft vegetation encounter a new food source of relatively hard but highly nutritious seeds. As the animals sample and eventually increase the representation of seeds in their diet, a number of developmental effects of their new diet become evident, including possible changes in body size and composition, fecundity, age of sexual maturation, and indirect changes in morphology. For example, as the diet changes from soft vegetation to harder seed items, the mechanical stresses exerted on growing jaw tissues during development change. Given that patterns of bone growth are known to be partly determined by forces exerted on the growing bone (Frost, 1973), the skeletal anatomy of the jaw is likely to be different in the animals that experience hard versus soft diets early in life. Such changes in diet have been shown to affect the jaw and skull of rats (Bouvier \& Hylander, 1984) and the teeth of primates (Corruccini \& Beecher, 1982), and Johnston and Gottlieb pointed out that such findings suggest that changes in jaw and tooth anatomy found in the fossil record are likely due in large part to the mechanical effects of dietary change and not to the often-invoked creative forces of natural selection.

It is important that what is considered to be an instance of phenotypic change (in this case, anatomical modification of the jaw) occurs prior to any changes in gene frequency. In this scenario, a given phenotypic change (such as preference for a new diet) leads to specific anatomical changes. Such changes can endure across generations and, as long as the new diet remains

\footnotetext{
${ }^{4}$ Note that these previously recognized factors of phenotypic change all refer to gene-level processes, a line of thinking that reflects the genecentered view that characterized much of biology during the last half of the 20th century. Recognizing that changes in development can bring about phenotypic change is one of the tenets of the evo-devo approach within contemporary biology (see Burian, 2000).
} 
available, may eventually lead to changes in gene frequency as a result of long-term behavioral or geographic isolation among variants within the population. Gottlieb (2002) has provided a succinct overview of this theory that evolution (defined as enduring transgenerational phenotypic change) can occur at the behavioral, anatomical, and physiological levels before it occurs at the genetic level. It is important to note that this approach does not require the "genetic assimilation" of developmental modifications or some form of neo-Larmarkism, in which nongenetic influences lead to genetic alterations within a given generation (see van der Weele, 1999, for further discussion). Rather, new phenotypes can arise from changes in behavior before they influence gene frequencies in future generations. Slobodkin and Rapoport (1974) explored the possible temporal order and relationships of this pathway, suggesting that changes in behavior, physiology, and other acclimatization mechanisms resulting from environmental perturbation could often precede genetic changes.

Phenotypic form and variation cannot simply be a consequence of natural selection, a position implicitly assumed and promoted throughout evolutionary psychology (Buss et al., 1998; Tooby \& Cosmides, 1990a, 1990b). Available evidence from developmental biology and developmental genetics indicates that developmental processes serve to guide and constrain phenotypic variation and thereby directly influence how selection can affect organisms (Kirschner \& Gerhart, 1998; Wagner \& Altenberg, 1996). Natural selection certainly plays an important role in evolution, but it is developmental processes that provide the creative force for evolutionary change (Bjorklund \& Pellegrini, 2002; Gottlieb, 1987, 2002). Simply put, developmental dynamics are involved in both the stability and the variability of phenotypic traits and characters across generations.

\section{Toward a Biologically Plausible Evolutionary Psychology}

In this article we have critically examined several of the underlying, often implicit assumptions adopted in recent attempts to unite evolutionary with psychological perspectives on human behavior and development. These assumptions include the following.

Phenotypic traits or characters can be prespecified in advance of individual ontogeny.

Genes contain the program or instructions for the prespecification of phenotypic traits; environment or experience simply provides the trigger for these programs to be expressed.

Genes are encapsulated and immutable to extragenetic influences; their causal role in development is fixed, and they provide the only reliable source of transgenerational inheritance of phenotypic traits and characters.

The creative, novelty-generating power of genetic mutations and natural selection is adequate to account for the range and nature of adaptations found within a population.

We have argued that these assumptions are no longer tenable given the empirical and conceptual advances that have taken place in the biological sciences over the past several decades. It is somewhat ironic that at a time when gene-centered explanations of behavior and cognition are increasingly obvious in psychological sciences, mounting evidence from genetics, embryology, and developmental biology is providing the basis for a more fully achieved epigenetic perspective on how organisms develop. This perspective is guided by an appreciation of the fundamental importance of developmental regulatory systems above and beyond the sequence information available in the genome.

This developmental dynamics approach explicitly rejects the outdated assumption that genes are the sole source of developmental information transmitted across generations and, in its place, promotes an expanded view of inheritance. This view proposes, on the basis of empirical evidence now emerging from the biological sciences, that what is inherited across generations is a structured developmental system that includes components internal (e.g., genes, cytoplasm, hormones) and external (e.g., diet, temperature, conspecifics) to the organism (see Griffiths \& Gray, 1994; Johnston, 1987; Oyama, 1985, 2000; West \& King, 1987). In other words, what offspring inherit from parents is not simply genes, but a structured developmental system. This developmental system provides sources of both stability and variability, and the structure and interactions among components of an organism's developmental system are as causally informative to the development and transmission of phenotypic traits as are the strands of DNA contained within this system. Definitions of inheritance that do not include components of the developmental system that are replicated in each generation and that play a role in the production of the life cycle of the organism are certain to be less than complete (Gray, 1992). What offspring inherit is not just a set of genes or a genetic program but a developmental system that utilizes genes and their products as resources (Richardson, 1998). As a result, the focus of a developmental dynamics approach is primarily on the discovery and understanding of the distributed causal relations among the multiple factors that make up the gene-in-a-cell-in-anorganism-in-an-environment system (Mahner \& Bunge, 1997; Oyama et al., 2001; Rollo, 1995).

A developmental dynamics perspective rejects the assumption of any vital force that oversees or controls development, as well as argues against any prespecification of traits or characters. Instead, development is seen as a self-organizing, probabilistic process in which pattern and order emerge and change as a result of complex interactions among developmentally relevant components both internal (including genes) and external to the organism, not from some set of prespecified instructions (see Sole \& Goodwin, 2001; Thelen \& Smith, 1994, 1998). This focus on the ontogenetic construction of phenotypes undermines any meaningful opposition between genetic and environmental sources of information for development, a framework common to both evolutionary psychology and behavior genetics (e.g., Segal \& MacDonald, 1998). In this sense, a developmental dynamics approach to how organisms develop adheres to a dialectical model of causality and determination (Levins \& Lewontin, 1985; Lewontin, 1991; S. Rose, 1998), in which emphasis is placed on explaining how stability and variability is achieved and maintained in living, historical systems (Butterworth, 1994; Holland, 1994; Stewart \& Cohen, 1997). Given that genes are but one component in a structured system of components across many levels, they cannot be offered as the cause of development. They are necessary conditions for developmental outcomes, and they have codeterminative power, but genes in and of themselves have no direct causal power (Coen, 1999; Dover, 2000; Moore, 2002). 
A developmental dynamics perspective allows researchers to abandon popular yet misleading metaphorical references to gene action (e.g., genes as the storehouse of information or programs for development, genes as the overseers or regulators of development) in favor of characterizing gene activity as a molecular, intracellular event (Johnston \& Edwards, 2002). Such an approach emphasizes the unpacking of the mechanics of developmental processes and would include (as first steps) coordinated interdisciplinary efforts to (a) systematically identify individual DNA sequences and their associated products, (b) determine the nongenetic factors involved in constructing and regulating the structure and function of the these products, (c) trace these products and their influence across the various levels of organization that make up the individual organism, and (d) determine how previous developmental outcomes and current experiences influence these processes in ecologically meaningful contexts (see Wagner, Chiu, \& Laubichler, 2000, for a similar evo-devo view). The psychological sciences have much to offer in this effort, particularly to explain how previous developmental outcomes and current experiences influence these biological processes in specific contexts.

Viewing genes as reciprocal partners in the developmental processes underlying phenotypic traits and characters requires a shift in the way the "environment" is typically characterized in discussions of both development and evolution. From a developmental dynamics framework, the environment cannot be reduced to "supportive conditions" or to an abstract "poser of problems" that must be solved-both common perspectives within contemporary evolutionary psychology. Rather, the specific physical, biological, and social environments within which the individual organism develops are recognized to be inseparable parts of the developmental system. Hence, the organism and its environment are best characterized as codefining (Turvey \& Shaw, 1995), and evolution can be seen to result from a dialectical interaction between organisms and environments through ontogeny (Levins \& Lewontin, 1985). Attempts to rigidly dichotomize the contributions of the organism and its environment to development or evolution typically lead to the need to invoke other troubling and unnecessary dichotomies, including the nondevelopmental phylogenetic-ontogenetic causal framework reviewed in previous sections and widely embraced by evolutionary psychologists. Whereas such dichotomies have allowed evolutionary psychologists to virtually ignore developmental dynamics in their accounts of human development and behavior (by arguing that they are interested in phylogenetic rather than ontogenetic questions), we argue that evolutionary and developmental frameworks do not provide fundamentally different ways of explaining behavior. Rather, developmental processes are fundamental both to individual development and to evolutionary change.

Instead of asking reductionistic questions about the genetic basis of human development and behavior, a developmental dynamics approach is interested in what are the contributions of the various components and levels of the organism-environment system and their interactions to phenotypic outcome. This empirically based unpacking of the mechanics of developmental processes requires going beyond the notion of the causal powers of the gene and focusing on the broader relational principles that govern and constrain development and evolution. As a case in point, there is compelling comparative evidence indicating that modified early experience in one generation can predictably influence phenotypic outcomes in subsequent generations, even in the absence of the original modification. Differences in physical (body weight, endocrine responses) and behavioral (fearfulness) measures have consistently been observed between groups of rats whose mothers (Denenberg \& Whimbey, 1963; Francis, Diorio, Liu, \& Meaney, 1999; Whimbey \& Denenberg, 1967) or grandmothers (Denenberg \& Rosenberg, 1967) were handled or not handled as infants. Evolutionary psychologists have rarely addressed these "proximate" causes of phenotypic development, viewing them as somehow separate and distinct from more fundamental preontogenetic or "ultimate" causes, which are thought to operate before individual development actually begins (e.g., Charlesworth, 1986). However, as reviewed in earlier sections, posing such dichotomous explanations for aspects of development and behavior does not explain how particular traits or characters are actually realized in an individual, nor does it describe the conditions, contexts, or developmental resources necessary for such outcomes to reliably occur within or across generations. If evolutionary psychology's aim is to understand the evolved psychological mechanisms that underlie behavior and the selective forces that have shaped these mechanisms (see Buss, 1999; Symons, 1992), then it seems to us that uncovering the network of factors (both internal and external to the organism) that bring about and maintain (or eliminate) transgenerational similarities or differences in behavioral traits should be a prominent goal of evolutionary psychology. It is remarkable how little attention these sorts of specifics receive in most writing in evolutionary psychology.

The combination of new theoretical approaches (that include an appreciation of the role of development in evolution) and detailed empirical studies of the life histories of both animals (in collaboration with comparative psychologists) and humans (in collaboration with developmental psychologists) could provide evolutionary psychology the means to retire the worn metaphor of genes as programs or blueprints in favor of a more contingent, dynamic, and biologically plausible view of how organisms develop. Such a shift would redirect evolutionary psychology's current scope and goals away from extreme forms of theoretical reductionism and toward a more integrated synthesis of development and evolution. For instance, although evolutionary psychology's enduring interest in topics such as sex differences in mate-choice criteria (e.g., Buss, 1989) and patterns of parental solicitude and investment by genetic versus step fathers (Daly \& Wilson, 1981) has generated a number of gene-centered hypotheses regarding the evolution of human reproductive strategies (see Buss, 1994; Daly \& Wilson, 1999), such interest has not translated into an empirical concern with (a) how an individual's reproductive behavior is guided and constrained by the set of physical, biological, and social factors with which it interacts over the course of development or (b) how human reproductive strategies are transmitted, maintained, or modified across generations. Bridging the gap between these kinds of developmental and evolutionary concerns by using multiple levels of analyses (including genetics, developmental biology, neuroscience, psychology, and anthropology) is at the heart of a developmental dynamics approach and could substantially inform about both developmental and evolutionary mechanisms thought to direct and constrain the complex relationship between genetic and environmental influences on human behavior and development. 


\section{Conclusions}

In our view, gene-centered approaches to human behavior and development are no longer tenable given the current state of knowledge in the biological and psychological sciences. Such views represent an unnecessarily reductionistic view of the emergence and maintenance of phenotypic traits by treating genes as causal agents with closed programs. They also serve to hinder empirical and theoretical progress by implying that investigators interested in evolutionary issues can ignore or downplay the fundamental significance of development. As a result, a number of psychologists continue to take for granted that behavior is somehow determined by more fundamental or primary processes that occur at the genetic level. This unidirectional, bottom-up view of the causes of behavior overlooks much of the conceptual and empirical content of contemporary biology, which shows that genetic factors are always part and parcel of the individual organism's entire developmental system. No single element or level in the system necessarily has causal primacy or privilege, and the functional significance of genes or any other influence on behavior development can be understood only in relation to the developmental system of which they are a part.

A biologically plausible evolutionary psychology requires a conceptual framework that rejects the notion of the prespecification of phenotypic outcomes and acknowledges the contingent and dynamic nature of developmental processes. We have proposed an epigenetic, developmental dynamics approach for this task. This approach seeks to integrate relevant data from genetics, developmental biology, embryology, neuroscience, and psychology into a more coherent and complementary account of how organisms develop and evolve. This approach transcends the dichotomies of nature and nurture, gene and environment, inherited and acquired (Johnston, 1987) and argues for an explanation of human behavior and development that draws from all relevant levels of influence, from molecular to environmental. Such a dynamic, multidetermined view is in keeping with recent advances in both developmental theory (Ford \& Lerner, 1992; Gottlieb, 1991; Lerner, 1998, 2002; Thelen \& Smith, 1994, 1998) and evolutionary theory (Depew \& Weber, 1995; Gottlieb, 1992; Gould, 2002; B. K. Hall, 1999; Lewontin, 2000; Raff, 1996) and provides a framework that is biologically plausible, acknowledges the complex and contingent nature of development, and integrates data from multiple levels of analysis.

This developmental dynamics approach provides evolutionary psychology a valuable conceptual framework to begin the complex task of incorporating what has been the black box of development into its theories of psychological mechanisms and processes. By explicitly not making a distinction between genetic and environmental sources for phenotypic traits, a developmental dynamics approach allows for an evolutionary perspective of human behavior that moves beyond outdated notions of genetically or environmentally determined development. In our view, a critical step in resolving questions about the evolution of complex psychological processes will be to examine them from an integrated developmental perspective. This perspective will require a redirection of evolutionary psychology's current scope and goals (see also Bjorklund \& Pellegrini, 2000) and has the potential to achieve a fuller and more useful integration of evolutionary and developmental psychology.

\section{References}

Allman, W. F. (1994). The Stone Age present: How evolution has shaped modern life. New York: Simon \& Schuster.

Barkow, J., Cosmides, L., \& Tooby, J. (1992). The adapted mind: Evolutionary psychology and the generation of culture. New York: Oxford University Press.

Baron-Cohen, S. (1995). Mindblindness: An essay on autism and theory of mind. Cambridge, MA: MIT Press.

Barton, N., \& Partridge, L. (2000). Limits to natural selection. BioEssays, 22, 1075-1084.

Bereczkei, T. (2000). Evolutionary psychology: A new perspective in the behavioral sciences. European Psychologist, 5, 175-190.

Beurton, P. J., Falk, R., \& Rheinberger, H.-J. (2000). The concept of the gene in development and evolution: Historical and epistemological perspectives. New York: Cambridge University Press.

Bjorklund, D. F., \& Pellegrini, A. D. (2000). Child development and evolutionary psychology. Child Development, 71, 1687-1708.

Bjorklund, D. F., \& Pellegrini, A. D. (2002). The origins of human nature: Evolutionary developmental psychology. Washington, DC: American Psychological Association.

Bouvier, M., \& Hylander, W. L. (1984). The effects of dietary consistency on gross and histologic morphology in the cranio-facial region of young rats. American Journal of Anatomy, 170, 117-126.

Brandon, R. N. (1996). Concepts and methods in evolutionary biology. Cambridge, England: Cambridge University Press.

Buller, D. J., \& Hardcastle, V. G. (2000). Evolutionary psychology, meet developmental neurobiology: Against promiscuous modularity. Brain and Mind, 1, 307-325.

Burian, R. M. (1986). On integrating the study of evolution and development. In W. Bechtel (Ed.), Integrating scientific disciplines (pp. 209228). Dordrecht, the Netherlands: Nijhoff.

Burian, R. M. (2000). General introduction to the symposium on evolutionary developmental biology: Paradigms, problems, and prospects. American Zoologist, 40, 711-717.

Buss, D. M. (1989). Sex differences in human mate preferences: Evolutionary hypotheses tested in 37 cultures. Behavioral and Brain Sciences, 12, 1-49.

Buss, D. M. (1991). Evolutionary personality psychology. Annual Review of Psychology, 45, 459-491.

Buss, D. M. (1994). The evolution of desire. New York: Basic Books.

Buss, D. M. (1995). Evolutionary psychology: A new paradigm for psychological science. Psychological Inquiry, 6, 1-30.

Buss, D. M. (1999). Evolutionary psychology: The new science of mind. Needham Heights, MA: Allyn \& Bacon.

Buss, D. M. (2000). The dangerous passion: Why jealousy is as necessary as love and sex. New York: Free Press.

Buss, D. M., Haselton, M. G., Shackelford, T. K., Bleske, A. L., \& Wakefield, J. C. (1998). Adaptations, exaptations, and spandrels. American Psychologist, 53, 533-548.

Buss, D. M., \& Schmitt, D. P. (1993). Sexual strategies theory: A contextual evolutionary analysis of human mating. Psychological Review, 100, 204-232.

Buss, D. M., \& Shackelford, T. K. (1997). From vigilance to violence: Mate retention tactics in married couples. Journal of Personality and Social Psychology, 72, 346-361.

Butterworth, G. (1994). Dynamic approaches to infant perception and action: Old and new theories about the origins of knowledge. In E Thelen \& L. B. Smith (Eds.), A dynamic systems approach to development: Applications (pp. 171-193). Cambridge, MA: MIT Press.

Cairns, R. B. (1998). The making of developmental psychology. In W. Damon (Series Ed.) \& R. M. Lerner (Vol. Ed.), Handbook of child psychology: Vol. 1. Theoretical models of human development (5th ed., pp. 419-448). New York: Wiley. 
Cairns, R. B., Elder, G. H., \& Costello, E. J. (1996). Developmental science. New York: Cambridge University Press.

Cairns, R. B., Gariepy, J.-L., \& Hood, K. E. (1990). Development, microevolution, and social behavior. Psychological Review, 97, 49-65.

Caporael, L. R. (2001). Evolutionary psychology: Toward a unifying theory and a hybrid science. Annual Review of Psychology, 52, 607-628.

Caruthers, P., \& Chamberlain, A. (2000). Evolution and the human mind. New York: Cambridge University Press.

Casey, M. B., \& Lickliter, R. (1998). Prenatal visual experience influences the development of turning bias in bobwhite quail. Developmental Psychobiology, 32, 327-338.

Casey, M. B., \& Martino, C. (2000). Asymmetrical hatching behaviors influence the development of postnatal laterality in domestic chicks. Developmental Psychobiology, 37, 13-24.

Charlesworth, W. R. (1986). Darwin and developmental psychology: 100 years later. Human Development, 29, 1-35.

Chisholm, J. (1999). Death, hope, and sex: Steps to an evolutionary ecology of mind and morality. New York: Cambridge University Press.

Chomsky, N. (1980). Rules and representations. Oxford, England: Blackwell.

Clark, M. M., \& Galef, B. G. (1995). Parental influence on reproductive life history strategies. Trends in Ecology and Evolution, 10, 151-153.

Clark, M. M., Karpiuk, P., \& Galef, B. G., Jr. (1993, August 19). Hormonally mediated inheritance of acquired characteristics in Mongolian gerbils. Nature, 364, 712-716.

Clayton, D. F. (2000). The genomic action potential. Neurobiology of Learning and Memory, 74, 185-216.

Coen, E. (1999). The art of genes: How organisms make themselves. Oxford, England: Oxford University Press.

Cohen, M. J., \& Tickle, C. (1999, June 3). Developmental basis of limblessness and axial patterning in snakes. Nature, 399, 474-479.

Collins, R. L. (1977). Toward an admissible genetic model for the inheritance of the degree and direction of asymmetry. In S. Harnard, R. Doty, L. Goldstein, J. Jaynes, \& G. Krauthamer (Eds.), Lateralization in the nervous system (pp. 137-150). New York: Academic Press.

Coltheart, M. (1999). Modularity and cognition. Trends in Cognitive Sciences, 3, 115-120.

Corruccini, R. S., \& Beecher, R. M. (1982, April 8). Occlusal variation related to soft diet in a nonhuman primate. Science, 218, 74-76.

Cosmides, L. (1989). The logic of social exchange: Has natural selection shaped how humans reason? Cognition, 31, 187-276.

Cosmides, L., \& Tooby, J. (1994a). Beyond intuition and instinct blindness: Toward an evolutionary rigorous cognitive science. Cognition, 50, 41-77.

Cosmides, L., \& Tooby, J. (1994b). Origins of domain specificity: The evolution of functional organization. In L. A. Hirschfeld \& S. A. Gelman (Eds.), Mapping the mind: Domain specificity in cognition and culture (pp. 85-116). New York: Cambridge University Press.

Cosmides, L., \& Tooby, J. (1997a). Dissecting the computational architecture of social inference mechanisms. In T. D. Eells (Ed.), Ciba Foundation Symposium: No. 208. Characterizing human psychological adaptations (pp. 132-161). Chichester, England: Wiley.

Cosmides, L., \& Tooby, J. (1997b). Evolutionary psychology: A primer. Retrieved January 14, 2002, from the University of California, Santa Barbara, Center for Evolutionary Psychology Web site: http://www .psych.ucsb.edu/research/cep/primer.html

Crawford, C. (1998). The theory of evolution in the study of human behavior: An introduction and overview. In C. Crawford \& D. L. Krebs (Eds.), Handbook of evolutionary psychology: Ideas, issues, and applications (pp. 3-41). Hillsdale, NJ: Erlbaum.

Crawford, C., \& Krebs, D. L. (1998). Handbook of evolutionary psychology: Ideas, issues, and applications. Hillsdale, NJ: Erlbaum.

Crick, F. (1970, August 8). Central dogma of molecular biology. Nature, 227, 561-563.
Cummins, D. D., \& Allen, C. (1998). The evolution of mind. New York: Oxford University Press.

Curran, T., Smeyne, R., Robertson, L., Vendrell, M., \& Morgan, J. I. (1994). FoslacZ expression: A transgenic approach to gene activation in the brain. In S. Zalcman, R. Scheller, \& R. Tsien (Eds.), Molecular neurobiology: Proceedings of the second NIMH conference (pp. 165172). Rockville, MD: National Institute of Mental Health.

Daly, M., \& Wilson, M. (1978). Sex, evolution, and behavior. North Scituate, MA: Duxbury Press.

Daly, M., \& Wilson, M. (1981). Abuse and neglect of children in evolutionary perspective. In R. Alexander \& D. W. Tinkle (Eds.), Natural selection and social behavior (pp. 405-416). New York: Chiron Press.

Daly, M., \& Wilson, M. (1999). The truth about Cinderella: A Darwinian view of parental love. New Haven, CT: Yale University Press.

Davidson, E. H. (1986). Gene activity in early development. Orlando, FL: Academic Press.

Davidson, E. H. (2001). Genomic regulatory systems: Development and evolution. New York: Academic Press.

Davies, P. S. (1999). The conflict of evolutionary psychology. In V. G. Hardcastle (Ed.), Where biology meets psychology: Philosophical essays (pp. 67-82). Cambridge, MA: MIT Press.

Dawkins, R. (1976). The selfish gene. Oxford, England: Oxford University Press.

Deacon, T. W. (1997). The symbolic species: The co-evolution of language and the brain. New York: Norton.

deBeer, G. (1940). Embryos and ancestors. Oxford, England: Clarendon Press.

de Jong, H. L., \& Van der Steen, W. J. (1998). Biological thinking in evolutionary psychology: Rockbottom or quicksand? Philosophical Psychology, 11, 183-205.

Denenberg, V. H. (1981). Hemispheric laterality in animals and the effects of early experience. Behavioral and Brain Sciences, 4, 1-49.

Denenberg, V. H., \& Rosenberg, K. M. (1967, November 11). Nongenetic transmission of information. Nature, 216, 549-550.

Denenberg, V. H., \& Whimbey, A. E. (1963, November 29). Behavior of adult rats is modified by the experiences their mothers had as infants. Science, 142, 1192-1193.

Dennett, D. C. (1995). Darwin's dangerous idea: Evolution and the meanings of life. New York: Simon \& Schuster.

Depew, D. J., \& Weber, B. H. (1995). Darwinism evolving: System dynamics and the genealogy of natural selection. Cambridge, MA: MIT Press.

Dobzhansky, T. (1951). Genetics and the origin of species (3rd ed.). New York: Columbia University Press.

Dover, G. (2000). Dear Mr. Darwin: Letters on the evolution of life and human nature. Berkeley: University of California Press.

Edelman, G. M. (1988). Topobiology. New York: Basic Books.

Edelman, G. M. (1989). The remembered present: A biological theory of consciousness. New York: Basic Books.

Edelman, G. M., \& Tononi, G. (2000). The universe of consciousness: How matter becomes imagination. New York: Basic Books.

Ellis, B. J. (1998). The partner-specific investment inventory: An evolutionary approach to individual differences in investment. Journal of Personality, 66, 383-442.

Endler, J. A. (1986). Natural selection in the wild. Princeton, NJ: Princeton University Press.

Falk, R. (2000). The gene: A concept in tension. In P. J. Burton, R. Falk, \& H.-J. Rheinberger (Eds.), The concept of the gene in development and evolution: Historical and epistemological perspectives (pp. 317-348). New York: Cambridge University Press.

Ferguson-Smith, A. C., \& Surani, M. A. (2001, August 10). Imprinting and the epigenetic asymmetry between parental genomes. Science, 293, 1086-1089.

Fodor, J. (1983). The modularity of mind. Cambridge, MA: MIT Press. 
Ford, D. H., \& Lerner, R. M. (1992). Developmental systems theory: An integrative approach. Newbury Park, CA: Sage.

Francis, D., Diorio, J., Liu, D., \& Meaney, M. J. (1999, November 5). Nongenomic transmission across generations of maternal behavior and stress responses in the rat. Science, 286, 1155-1158.

Frost, H. M. (1973). Bone remodeling and skeletal modeling errors. Springfield, MA: Thomas.

Gans, C., \& Crews, D. (1992). Hormones, brain, and behavior: Biology of the reptiles. Chicago: University of Chicago Press.

Gardner, H. (1984). Frames of mind: The theory of multiple intelligences. London: Heinemann.

Gaulin, S. J. C., \& McBurney, D. H. (2002). Psychology: An evolutionary approach. New York: Prentice Hall.

Gazzaniga, M. S. (1992). Nature's mind. New York: Basic Books.

Geary, D. C., \& Bjorklund, D. F. (2000). Evolutionary developmental psychology. Child Development, 71, 57-65.

Gerhart, J., \& Kirschner, M. (1997). Cells, embryos, and evolution. Oxford, England: Blackwell Scientific.

Gerrans, P. (2002). Modularity reconsidered. Language and Communication, 22, 259-268.

Gigerenzer, G., \& Hug, K. (1992). Domain-specific reasoning: Social contracts, cheating, and perspective change. Cognition, 43, 127-171.

Gilbert, S. F. (1991). Cytoplasmic action in development. Quarterly Review of Biology, 66, 309-316.

Gilbert, S. F. (1994). Dobzhansky, Waddington, and Schmalhausen: Embryology and the modern synthesis. In M. B. Adams (Ed.), The evolution of Theodosius Dobzhansky (pp. 143-154). Princeton, NJ: Princeton University Press.

Gilbert, S. F. (2000). Developmental biology (6th ed.). Sunderland, MA: Sinauer.

Gilbert, S. F. (2001). Ecological developmental biology: Developmental biology meets the real world. Developmental Biology, 233, 1-12.

Gilbert, S. F., \& Burian, R. M. (in press). Evolutionary developmental biology. In B. K. Hall \& W. M. Olson (Eds.), Keywords and concepts in evolutionary developmental biology. Cambridge, MA: Harvard University Press.

Gilbert, S. F., Opitz, J. M., \& Raff, R. A. (1996). Resynthesizing evolutionary and developmental biology. Developmental Biology, 173, 357372.

Goldhaber, D. E. (1999). Theories of human development: Integrative perspectives. Mountain View, CA: Mayfield.

Goldschmidt, R. (1940). The material basis of evolution. New Haven, CT: Yale University Press.

Goldschmidt, R. (1950). "Repeats" and the modern theory of the gene. Proceedings of the National Academy of Sciences, USA, 56, 365-367.

Goldschmidt, R. (1951). The theory of the gene. Cold Spring Harbor Symposium on Quantitative Biology, 16, 1-11.

Goodwin, B. C., Holder, N., \& Wylie, C. C. (1983). Development and evolution. New York: Cambridge University Press.

Gottlieb, G. (1987). The developmental basis of evolutionary change. Journal of Comparative Psychology, 101, 262-271.

Gottlieb, G. (1991). Experiential canalization of behavioral development: Theory. Developmental Psychology, 27, 4-13.

Gottlieb, G. (1992). Individual development and evolution: The genesis of novel behavior. New York: Oxford University Press.

Gottlieb, G. (1995). Some conceptual deficiencies in "developmental" behavior genetics. Human Development, 38, 131-141.

Gottlieb, G. (1997). Synthesizing nature-nurture: Prenatal roots of instinctive behavior. Mahwah, NJ: Erlbaum.

Gottlieb, G. (1998). Normally occurring environmental and behavioral influences on gene activity: From central dogma to probabilistic epigenesis. Psychological Review, 105, 792-802.

Gottlieb, G. (2001). A developmental psychobiological systems view: Early formulation and current status. In S. Oyama, P. E. Griffiths, \& R.
Gray (Eds.), Cycles of contingency: Developmental systems and evolution (pp. 41-54). Cambridge, MA: MIT Press.

Gottlieb, G. (2002). Developmental-behavioral initiation of evolutionary change. Psychological Review, 109, 211-218.

Gottlieb, G., Wahlsten, D., \& Lickliter, R. (1998). The significance of biology for human development: A developmental psychobiological systems view. In W. Damon (Series Ed.) \& R. M. Lerner (Vol. Ed.), Handbook of child psychology: Vol. 1. Theoretical models of human development (5th ed., pp. 233-273). New York: Wiley.

Gould, S. J. (2002). The structure of evolutionary theory. Cambridge, MA: Harvard University Press.

Gray, R. D. (1992). Death of the gene: Developmental systems strike back. In P. E. Griffiths (Ed.), Trees of life: Essays in the philosophy of biology (pp. 163-209). Boston: Kluwer.

Griffiths, P. E., \& Gray, R. D. (1994). Developmental systems and evolutionary explanation. Journal of Philosophy, 91, 277-304.

Griffiths, P. E., \& Neumann-Held, E. M. (1999). The many faces of the gene. Bioscience, 49, 656-662.

Haeckel, E. (1879). Anthropogenie [Anthropology] (3rd ed.). Leipzig, Germany: Engelmann.

Hall, B. K. (1994). Homology: The hierarchical basis of comparative anatomy. New York: Academic Press.

Hall, B. K. (1999). Evolutionary developmental biology (2nd ed.). Boston: Kluwer.

Hall, G. S. (1904). Adolescence: Its psychology and its relations to physiology, anthropology, sociology, sex, crime, religion, and education. New York: Appleton.

Harrison, R. (1937, April 16). Embryology and its relations. Science, 85, 369-374.

Hegarty, C. M., Jonassent, J. A., \& Bittman, E. L. (1990). Pituitary hormone gene expression in male golden hamsters: Interactions between photoperiod and testosterone. Journal of Neuroendocrinology, 2, 567573.

Hirschfeld, L. A., \& Gelman, S. A. (1994). Mapping the mind: Domain specificity in cognition and culture. New York: Cambridge University Press.

Ho, M.-W. (1984). Environment and heredity in development and evolution. In M.-W. Ho \& P. T. Saunders (Eds.), Beyond neo-Darwinism: An introduction to the new evolutionary paradigm (pp. 267-289). San Diego, CA: Academic Press.

Ho, M.-W., \& Fox, S. W. (1988). Evolutionary processes and metaphors. New York: Wiley.

Holland, J. H. (1994). Hidden order: How adaptation builds complexity. Cambridge, MA: Perseus.

Holliday, R. (1990). Mechanisms for the control of gene activity during development. Biological Reviews, 65, 431-471.

Hughes, P., \& Dragunow, M. (1995). Induction of immediate-early genes and the control of neurotransmitter-regulated gene expression within the nervous system. Pharmocological Review, 47, 133-178.

Ingold, T. (2000). Evolving skills. In H. Rose \& S. Rose (Eds.), Alas, poor Darwin: Evidence against evolutionary psychology (pp. 273-298). New York: Harmony Books.

Ingold, T. (2001). From the transmissions of representations to the education of attention. In H. Whitehouse (Ed.), The debated mind: Evolutionary psychology verses ethnography (pp. 113-153). New York: Berg.

Jablonka, E. (2001). The systems of inheritance. In S. Oyama, P. E. Griffiths, \& R. D. Gray (Eds.), Cycles of contingency: Developmental systems and evolution (pp. 99-116). Cambridge, MA: MIT Press.

Jablonka, E., \& Lamb, M. J. (1995). Epigenetic inheritance and evolution. New York: Oxford University Press.

Jacob, F. (1982). The possible and the actual. New York: Pantheon.

Jenuwein, T., \& Allis, C. D. (2001, August 10). Translating the histone code. Science, 293, 1074-1079.

Johnston, T. D. (1985). Environmental constraints and the natural context 
of behavior: Grounds for an ecological approach to the study of infant perception. In G. Gottlieb \& N. A. Krasnegor (Eds.), Measurement of audition and vision in the first year of postnatal life (pp. 91-108). Norwood, NJ: Ablex.

Johnston, T. D. (1987). The persistence of dichotomies in the study of behavioral development. Developmental Review, 7, 149-182.

Johnston, T. D. (1995). The influence of Weismann's germ-plasm theory on the distinction between learned and innate behavior. Journal of the History of the Behavioral Sciences, 31, 115-128.

Johnston, T. D., \& Edwards, L. (2002). Genes, interactions, and development. Psychological Review, 109, 26-34.

Johnston, T. D., \& Gottlieb, G. (1990). Neophenogenesis: A developmental theory of phenotypic evolution. Journal of Theoretical Biology, 147, 471-495.

Jones, D. (1999). Evolutionary psychology. Annual Review of Anthropology, 28, 553-575.

Jones, P. A., \& Takai, D. (2001, August 10). The role of DNA methylation in mammalian epigenetics. Science, 293, 1068-1070.

Keller, E. F. (2000). The century of the gene. Cambridge, MA: Harvard University Press.

Kirschner, M., \& Gerhart, J. (1998). Evolvability. Proceedings of the National Academy of Sciences, USA, 95, 8420-8427.

Kitcher, P. (1992). Gene: Current usages. In E. F. Keller \& E. Lloyd (Eds.), Keywords in evolutionary biology (pp. 128-131). Cambridge, MA: Harvard University Press.

Lerner, R. M. (1998). Theories of human development: Contemporary perspectives. In W. Damon (Series Ed.) \& R. M. Lerner (Vol. Ed.), Handbook of child psychology: Vol. 1. Theoretical models of human development (5th ed., pp. 1-24). New York: Wiley.

Lerner, R. M. (2002). Concepts and theories of human development (3rd ed.). Mahwah, NJ: Erlbaum.

Levins, R., \& Lewontin, R. (1985). The dialectical biologist. Cambridge, MA: Harvard University Press.

Lewontin, R. C. (1991). Biology as ideology: The doctrine of DNA. New York: HarperCollins.

Lewontin, R. C. (2000). The triple helix. Cambridge, MA: Harvard University Press.

Lickliter, R. (2000). An ecological approach to behavioral development: Insights from comparative psychology. Ecological Psychology, 12, 319-334.

Lickliter, R., \& Berry, T. D. (1990). The phylogeny fallacy: Developmental psychology's misapplication of evolutionary theory. Developmental Review, 10, 348-364.

Lickliter, R., \& Ness, J. W. (1990). Domestication and comparative psychology: Status and strategy. Journal of Comparative Psychology, 104, 211-218.

Lloyd, E. A. (1999). Evolutionary psychology: The burdens of proof. Biology and Philosophy, 14, 211-233.

Lloyd, E. A., \& Feldman, M. W. (2002). Evolutionary psychology: A view from evolutionary biology. Psychological Inquiry, 13, 150-156.

Lorenz, K. (1965). Evolution and the modification of behavior. Chicago: University of Chicago Press.

Mack, K. J., \& Mack, P. A. (1992). Induction of transcription factors in somatosensory cortex after tactile stimulation. Molecular Brain Research, 12, 141-147.

Mahner, M., \& Bunge, M. (1997). Foundations of biophilosophy. New York: Springer.

Maynard Smith, J. M., Burian, R. M., Kaufmann, S. A., Alberch, P., Campbell, J., Goodwin, B. C., et al. (1985). Developmental constraints and evolution: A perspective from the Mountain Lake conference on development and evolution. Quarterly Review of Biology, 60, 265-287.

Mayr, E. (1961, November 10). Cause and effect in biology. Science, 134, $1501-1506$
Mayr, E. (1982). The growth of biological thought. Cambridge, MA: Harvard University Press.

Meaney, M. J., Diorio, J., Francis, D., Widdowson, J., LaPlante, P., Caldji, C., et al. (1996). Early environmental regulation of forebrain glucocorticoid receptor gene expression: Implications for adrenocortical responses to stress. Developmental Neuroscience, 18, 49-72.

Mello, C. V., Vicario, D. S., \& Clayton, D. F. (1992). Song presentation induces gene expression in the songbird forebrain. Proceedings of the National Academy of Sciences, USA, 89, 6818-6822.

Michel, G., \& Moore, C. (1995). Developmental psychobiology: An integrative science. Cambridge, MA: MIT Press.

Mivart, G. J. St. (1871). On the genesis of species. London: Macmillan.

Moore, D. S. (2002). The dependent gene: The fallacy of nature vs. nurture. New York: Freeman.

Moss, L. (2001). Deconstructing the gene and reconstructing molecular developmental systems. In S. Oyama, P. E. Griffiths, \& R. Gray (Eds.), Cycles of contingency: Developmental systems and evolution (pp. 8598). Cambridge, MA: MIT Press.

Muller, G. B., \& Steicher, J. (1989). Ontogeny of the syndesmosis tibiofibularis and the evolution of the bird hindlimb: A caenogenetic feature triggers phenotypic novelty. Anatomical Embryology, 179, 327-339.

Muller, G. B., \& Wagner, G. P. (1996). Homology, Hox genes, and developmental integration. American Zoologist, 36, 4-13.

Neumann-Held, E. M. (1998). The gene is dead-Long live the gene: Conceptualizing genes the constructionist way. In P. Koslowski (Ed.), Sociobiology and bioeconomics: The theory of evolution in biological and economic theory (pp. 105-137). Berlin, Germany: Springer-Verlag.

Newman, S. A., \& Muller, G. B. (2000). Epigenetic origins of character origination. In G. P. Wagner (Ed.), The character concept in evolutionary biology (pp. 559-579). San Diego, CA: Academic Press.

Nijhout, F. H. (1999). Control mechanisms of polyphenic development in insects. Bioscience, 49, 181-192.

Nijhout, F. H. (2001). The ontogeny of phenotypes. In S. Oyama, P. E. Griffiths, \& R. Gray (Eds.), Cycles of contingency: Developmental systems and evolution (pp. 129-140). Cambridge, MA: MIT Press.

Nisbett, R. E. (1990). Evolutionary psychology, biology, and cultural evolution. Motivation and Emotion, 14, 255-263.

Oyama, S. (1985). The ontogeny of information. Cambridge, England: Cambridge University Press.

Oyama, S. (2000). Evolution's eye. Durham, NC: Duke University Press.

Oyama, S., Griffiths, P. E., \& Gray, R. D. (2001). Cycles of contingency: Developmental systems and evolution. Cambridge, MA: MIT Press.

Pennisi, E. (2001, August 10). Behind the scenes of gene expression. Science, 293, 1064-1067.

Pigliucci, M. (2001). Phenotypic plasticity: Beyond nature and nurture. Baltimore, MD: Johns Hopkins University Press.

Pinker, S. (1994). The language instinct. New York: Morrow.

Pinker, S. (1997). How the mind works. New York: Norton

Pinker, S. (2002). The blank slate. New York: Viking.

Plotkin, H. (1994). Darwin machines and the nature of knowledge. Cambridge, MA: Harvard University Press.

Plotkin, H. (1998). Evolution in mind. Cambridge, MA: Harvard University Press.

Portin, P. (1993). The concept of the gene: Short history and present status. Quarterly Review of Biology, 68, 173-223.

Previc, F. H. (1991). A general theory concerning the prenatal origins of cerebral lateralization in humans. Psychological Review, 98, 299-334.

Pritchard, D. J. (1986). Foundations of developmental genetics. Philadelphia: Taylor \& Francis.

Provins, K. A. (1997). Handedness and speech: A critical reappraisal of the role of genetic and environmental factors in cerebral lateralization of function. Psychological Review, 104, 554-571.

Raff, R. A. (1996). The shape of life. Chicago: University of Chicago Press. 
Raff, R. A. (2000). Evo-devo: The evolution of a new discipline. Nature Reviews: Genetics, 1, 74-79.

Raff, R. A., \& Kaufman, T. C. (1983). Embryos, genes, and evolution: The developmental-genetic basis of evolutionary change. New York: Macmillan.

Rampon, C., Jiang, C., Dong, H., Tang, Y., Lockhart, D., Schultz, P., et al. (2000). Effects of environmental enrichment on gene expression in the brain. Proceedings of the National Academy of Sciences, USA, 97, 12880-12884.

Reik, W., Dean, W., \& Walter, J. (2001, August 10). Epigenetic reprogramming in mammalian development. Science, 293, 1089-1093.

Richardson, K. (1998). The origins of human potential: Evolution, development and psychology. London: Routledge.

Riedl, R. (1978). Order in living systems. New York: Wiley.

Robert, J. S., Hall, B. K., \& Olson, W. M. (2001). Bridging the gap between developmental systems theory and evolutionary developmental biology. BioEssays, 23, 954-962.

Rodgers, L. J. (1982, May 20). Light experience and asymmetry of brain function in chickens. Nature, 297, 223-225.

Rodgers, L. J. (1986). Lateralization of learning in chicks. Advances in the Study of Behavior, 16, 147-189.

Rodgers, L. J. (1995). The development of brain and behaviour in the chicken. Wallingford, England: CAB International.

Rollo, D. C. (1995). Phenotypes: Their epigenetics, ecology, and evolution. London: Chapman Hall.

Rose, H., \& Rose, S. (2000). Alas, poor Darwin: Arguments against evolutionary psychology. New York: Harmony Books.

Rose, S. (1998). Lifelines: Biology beyond determinism. New York: Oxford University Press.

Sameroff, A. J. (1983). Developmental systems: Contexts and evolution. In P. H. Mussen (Series Ed.) \& W. Kessen (Vol. Ed.), Handbook of child psychology: Vol. 1. History, theory, and methods (4th ed., pp. 237-294). New York: Wiley.

Samuels, R. (1998). Evolutionary psychology and the massive modularity hypothesis. British Journal for the Philosophy of Science, 49, 575-602.

Sarkar, S. (1998). Genetics and reductionism. New York: Cambridge University Press.

Schlichting, C. D., \& Pigliucci, M. (1998). Phenotypic evolution: A reaction norm perspective. Sunderland, MA: Sinauer.

Schmalhausen, I. I. (1949). Factors of evolution. Philadelphia, PA: Blakiston.

Scholl, B. J., \& Leslie, A. M. (1999). Modularity, development, and "theory of mind." Mind and Language, 14, 131-153.

Segal, N. L., \& MacDonald, K. B. (1998). Behavioral genetics and evolutionary psychology: Unified perspective on personality research. $\mathrm{Hu}$ man Biology, 70, 159-179.

Shapiro, D. Y. (1981, September 5). Serial female sex changes after simultaneous removal of males from social groups of a coral reef fish. Science, 209, 1136-1137.

Shepard, R. N. (1997). The genetic basis of human scientific knowledge. In T. D. Eells (Ed.), Ciba Foundation Symposium: No. 208. Characterizing human psychological adaptations (pp. 23-38). Chichester, England: Wiley.

Slobodkin, L. B., \& Rapoport, A. (1974). An optimal strategy of evolution. Quarterly Review of Biology, 49, 181-200.

Sober, E. (1993). The nature of selection: Evolutionary theory in philosophical focus. Chicago: University of Chicago Press.

Sober, E. (2000). Philosophy of biology (2nd ed.). Boulder, CO: Westview Press.

Sole, R., \& Goodwin, B. (2001). Signs of life: How complexity pervades biology. New York: Basic Books.

Spelke, E. S. (1994). Initial knowledge: Six suggestions. Cognition, 50, 431-445.

Spelke, E. S., Brienlinger, K., Macombre, J., \& Jacobson, K. (1992). Origins of knowledge. Psychological Review, 99, 605-632.
Spelke, E. S., \& Newport, E. L. (1998). Nativism, empiricism, and the development of knowledge. In W. Damon (Series Ed.) \& R. Lerner (Vol. Ed.), Handbook of child psychology: Vol. 1. Theoretical models of human development (5th ed., pp. 275-340). New York: Wiley.

Spencer, H. (1855). Principles of psychology. New York: Appleton.

Sperber, D. (1996). Explaining culture: A naturalistic approach. Oxford, England: Blackwell.

Sterelny, K., \& Griffiths, P. E. (1999). Sex and death: An introduction to the philosophy of biology. Chicago: University of Chicago Press.

Stewart, I., \& Cohen, J. (1997). Figments of reality: The evolution of the curious mind. New York: Cambridge University Press.

Strohman, R. C. (1997). The coming Kuhnian revolution in biology. Nature Biotechnology, 15, 194-200.

Symons, D. (1992). On the use and misuse of Darwinism in the study of human behavior. In J. Barkow, L. Cosmides, \& J. Tooby (Eds.), The adapted mind: Evolutionary psychology and the generation of culture (pp. 137-159). New York: Oxford University Press.

Symons, D. (1995). Beauty is in the adaptations of the beholder: The evolutionary psychology of human female attractiveness. In P. R. Abramsen (Ed.), Sexual nature, sexual culture (pp. 80-119). Chicago: University of Chicago Press.

Tischmeyer, W., \& Grimm, R. (1999). Activation of immediate early genes and memory formation. Cellular and Molecular Life Sciences, 55, 564574.

Thelen, E., Schoener, G., Scheier, C., \& Smith, L. B. (2001). The dynamics of embodiment: A field theory of infant preseverative reaching. Behavioral and Brain Sciences, 24, 1-86.

Thelen, E., \& Smith, L. B. (1994). A dynamic systems approach to the development of cognition and action. Cambridge, MA: MIT Press.

Thelen, E., \& Smith, L. B. (1998). Dynamic systems theories. In W. Damon (Series Ed.) \& R. M. Lerner (Vol. Ed.), Handbook of child psychology: Vol. 1. Theoretical models of human development (5th ed., pp. 563-634). New York: Wiley.

Tooby, J., \& Cosmides, L. (1989). Evolutionary psychology and the generation of culture: I. Theoretical considerations. Ethology and Sociobiology, 10, 29-49.

Tooby, J., \& Cosmides, L. (1990a). On the universality of human nature and the uniqueness of individuals: The role of genetics and adaptation. Journal of Personality, 58, 17-67.

Tooby, J., \& Cosmides, L. (1990b). The past explains the present: Emotional adaptations and the structure of ancestral environments. Ethology and Sociobiology, 11, 375-424.

Tooby, J., \& Cosmides, L. (1992). The psychological foundations of culture. In J. Barkow, L. Cosmides, \& J. Tooby (Eds.), The adapted mind: Evolutionary psychology and the generation of culture (pp. 19136). New York: Oxford University Press.

Tooby, J., \& Cosmides, L. (1995). Mapping the evolved functional organization of mind and brain. In M. S. Gazzaniga (Ed.), The cognitive neurosciences (pp. 1185-1197). Cambridge, MA: MIT Press.

Turkewitz, G. (1988). A prenatal source for the development of hemispheric specialization. In D. L. Molfese \& S. V. J. Segalowitz (Eds.), Developmental implications of brain lateralization (pp. 73-82). New York: Guilford Press.

Turkewitz, G. (1991). Perinatal influences on the development of hemispheric specialization and complex information processing. In M. L. Weiss \& P. R. Zelazo (Eds.), Newborn attention: Biological constraints and the influence of experience (pp. 443-465). Norwood, NJ: Ablex.

Turvey, M. T., \& Shaw, R. E. (1995). Toward an ecological physics and a physical psychology. In R. L. Solso \& D. W. Massaro (Eds.), The science of the mind: 2001 and beyond (pp. 144-169). New York: Oxford University Press.

van der Weele, C. (1999). Images of development: Environmental causes of ontogeny. Albany: State University of New York Press. 
Van Valen, L. (1973). A new evolutionary law. Evolutionary Theory, 1, $1-30$.

Vom Saal, F. S., \& Dhar, M. G. (1992). Blood flow in the uterine loop artery and loop vein is bidirectional in the mouse: Implications for transport of steroids between fetuses. Physiology and Behavior, 52, 163-171.

Waddington, C. H. (1940). Organisers and genes. Cambridge, England: Cambridge University Press.

Waddington, C. H. (1948). The genetic control of development. Symposium of the Society of Experimental Biology, 2, 145-154.

Waddington, C. H. (1957). The strategy of the genes. London: Allen \& Unwin.

Wagner, G. B., \& Altenberg, L. (1996). Complex adaptations and the evolution of evolvability. Evolution, 50, 967-976.

Wagner, G. B., Chiu, C.-H., \& Laubichler, M. (2000). Developmental evolution as a mechanistic science: The inference from developmental mechanisms to evolutionary processes. American Zoologist, 40, 819831

Weismann, A. (1889). Essays upon heredity. Oxford, England: Clarendon Press.

West, M. J., \& King, A. P. (1987). Settling nature and nurture into an ontogenetic niche. Developmental Psychobiology, 20, 549-562.
Whimbey, A. E., \& Denenberg, V. H. (1967). Experimental programming of life histories: The factor structure underlying experimentally created individual differences. Behaviour, 29, 296-314.

Williams, G. C. (1992). Natural selection: Domains, levels, and challenges. New York: Oxford University Press.

Wilson, E. O. (1975). Sociobiology. Cambridge, MA: Harvard University Press.

Wright, R. (1994). The moral animal: Evolutionary psychology and everyday life. New York: Pantheon.

Wright, S. (1968). Evolution and the genetics of populations: Vol. 1. Genetic and biometric foundations. Chicago: University of Chicago Press.

Zappia, J. V., \& Rodgers, L. J. (1983). Light experience during development affects asymmetry of forebrain function in chickens. Developmental Brain Research, 11, 93-106.

Received February 12, 2002

Revision received December 30, 2002

Accepted January 15, 2003

\title{
Call for Nominations: Health Psychology
}

Division 38 (Health Psychology) has opened nominations for the editorship of Health Psychology for the years 2006-2011. Arthur A. Stone, PhD, is the incumbent editor.

Candidates should be members of APA and should be available to start receiving manuscripts in early 2005 to prepare for issues published in 2006 . Please note that Division 38 encourages participation by members of underrepresented groups in the publication process and would particularly welcome such nominees. Self-nominations also are encouraged

Jerry Suls, PhD, has been appointed as chair for this search.

To nominate candidates, prepare a statement of one page or less in support of each candidate Address all nominations to

\author{
Barbara Keeton, APA Division 38 \\ Health Search Committee \\ P.O. Box 1838 \\ Ashland, VA 23005 \\ Email: apadiv38@erols.com
}

The first review of nominations will begin December 15, 2003. The deadline for accepting nominations is December 15, 2003. 


\section{Developmental Dynamics and Contemporary Evolutionary Psychology: Status Quo or Irreconcilable Views? Reply to Bjorklund (2003), Krebs (2003), Buss and Reeve (2003), Crawford (2003), and Tooby et al. (2003)}

\author{
Robert Lickliter \\ Florida International University
}

\author{
Hunter Honeycutt \\ Indiana University Bloomington
}

\begin{abstract}
The authors address commentaries by D. F. Bjorklund (2003); D. M. Buss and H. K. Reeve (2003); C. B. Crawford (2003); D. L. Krebs (2003); and J. Tooby, L. Cosmides, and H. C. Barrett (2003) on their analysis of the underlying assumptions of contemporary evolutionary psychology (R. Lickliter \& H. Honeycutt, 2003). The authors argue that evolutionary psychology currently offers no coherent framework for how to integrate genetic, environmental, and experiential factors into a theory of behavioral or cognitive phenotypes. The authors propose that this absence is due to a lack of developmental analysis in the major works of evolutionary psychology, resulting in an almost exclusive focus on adaptationist accounts of evolution by natural selection rather than a more broad-based focus on the process and products of evolution by epigenetic developmental dynamics.
\end{abstract}

The commentators on our article (Lickliter \& Honeycutt, 2003) raised a number of important issues, and several of their reactions are likely shared by other researchers attempting to integrate evolutionary thinking into the psychological sciences. Two general themes reappeared across the commentaries (Bjorklund, 2003; Buss \& Reeve, 2003; Crawford, 2003; D. L. Krebs, 2003; Tooby, Cosmides, \& Barrett, 2003): (a) Although development is acknowledged to be important in the achievement of phenotypic traits and characters, our critics argued that incorporating a developmental dynamics perspective will not substantially change the aims, methods, or concerns of evolutionary psychology-in other words, there is nothing in the developmental dynamics approach outlined in our article that is not consistent with the basic premises of evolutionary psychology, and (b) evolutionary psychologists are not predeterminists - they are fully aware that any phenotype depends on interactions between a genome and an environment, and we have thus addressed a straw man in our critical examination of evolutionary psychology's underlying assumptions. Our critics argued that we have constructed and deconstructed a framework for evolutionary psychology that no current practitioner would endorse.

In what follows we propose that the comments on our article (Lickliter \& Honeycutt, 2003) provide further evidence that the prespecified, instructionistic approach to understanding human development and evolution we highlighted is alive and well in evolutionary psychology. Furthermore, we reemphasize that evolutionary psychology currently offers no coherent framework for

Robert Lickliter, Department of Psychology, Florida International University; Hunter Honeycutt, Department of Psychology, Indiana University Bloomington.

Correspondence concerning this article should be addressed to Robert Lickliter, Department of Psychology, Florida International University, Miami, Florida 33199. E-mail: licklite@ fiu.edu how to integrate genetic and experiential factors into a theory of the phenotype. We argue that this absence is due in large part to a lack of developmental analysis in the major works of evolutionary psychology, resulting in an almost exclusive focus on adaptationist accounts of evolution by natural selection rather than a more broad-based focus on the process and products of evolution by developmental mechanisms. Our primary thesis is that the prespecified, nondevelopmental approach to evolution (implicitly or explicitly) espoused by evolutionary psychologists is not consistent with recent findings from the life sciences and therefore will ultimately fail to provide a plausible explanatory framework for understanding human behavior and development.

\section{The Relevance of Development to Evolutionary Issues}

One position shared among the commentators is that although an appreciation of development is important, any changes that would occur to evolutionary psychology by accepting a probabilistic epigenetic view of development would either be irrelevant (Crawford, 2003; D. L. Krebs, 2003) or would not significantly alter the basic aims and current focus of evolutionary psychology (Bjorklund, 2003; Buss \& Reeve, 2003; Tooby et al., 2003). We strongly disagree with these views. As recently pointed out by a number of biologists, psychologists, and philosophers, development and evolution can effectively be viewed as two sides of the same coin. The mechanisms of evolution are now considered to be essential to understanding development, and the mechanisms of development have likewise become essential to understanding evolution (e.g., Gilbert, 2000; Kirschner \& Gerhart, 1998; Moss, 2003; Oyama, Griffiths, \& Gray, 2001). This is the case because all phenotypic traits and characters arise during ontogeny as products of individual development. In other words, traits or characters (be they behavioral, cognitive, or otherwise) must be generated in individual ontogeny, regardless of whether they have an evolutionary history. As we pointed out in our article (Lickliter \& 
Honeycutt, 2003), evolutionary change primarily occurs by variation in the patterns of development that give rise to individual phenotypes. Development is thus a key factor in understanding evolution and its outcomes (see Alberch, 1982; Gottlieb, 1992; Oyama, 1985, for further discussion). This is not a new message. Writing over 60 years ago, the embryologist and geneticist Conrad Waddington (1941) argued that

a theory of evolution requires, as a fundamental part of it, some theory of development. Evolution is concerned with changes in animals, and it is impossible profitably to discuss changes in a system unless one has some picture of what the system is like. Since every aspect of an animal is a product of development, or rather is a temporary phase of a continuous process of development, a model of the nature of animal organization can only be given in developmental terms. (p. 108)

As we reviewed in our article (Lickliter \& Honeycutt, 2003), development guides and constrains evolution in at least two major ways: First, it constrains phenotypic variation in such a way that the traits and characters presented to the filter of natural selection are not random. This is the regulatory function of development. Second, development provides variants in traits and characters that may lead to enduring alterations of the phenotype. This production of phenotypic novelties is the generative function of development and has significant implications for evolutionary change (see Gottlieb, 1992, 2002). Recent evidence from embryology, developmental biology, and developmental psychology makes clear that the regulatory and generative nature of development renders the natural selection of random mutations (the cornerstone of the neo-Darwinian view of evolutionary change) insufficient to account for evolution and its outcomes. Rather, the individual organism's developmental system is the source of both the stability and the variations in phenotype that researchers in evolutionary biology and developmental psychology seek to better understand. This insight was a primary theme of our article and stands in contrast to the widespread assumption in evolutionary psychology that ontogeny and phylogeny can be alternative processes by which information is made available to developing individuals.

The interdependence of development and evolution has emerged as a dominant theme in the life sciences in the beginning of the 21 st century and, as we highlighted in our article, is leading to significant shifts in thinking about how to define genes (e.g., Keller, 2000; Moss, 2003), how to characterize heredity (e.g., Jablonka, 2001; Oyama et al., 2001; Raff, 1996), and how to attribute the role of natural selection in evolutionary change (e.g., Gottlieb, 1998; Gould, 2002), to mention only a few examples. The growing appreciation of the interdependence of development and evolution is also evident in the establishment of several new subdisciplines within biology, including evolutionary developmental biology. This "evo-devo" approach aims to integrate development and evolution in a coherent theory (Hall, 1999). Despite the growing effort to integrate development into evolutionary biology, we find no meaningful analysis of development in the major works defining evolutionary psychology (Tooby et al.'s, 2003, comments not withstanding), and our target article was designed in large part to offer a corrective to the nondevelopmental view of evolution that has been given to psychology by evolutionary psychologists. Bjorklund (2003) appreciated the importance of this effort in his commentary, but Buss and Reeve (2003), Crawford (2003), and D. L. Krebs (2003) remained unconvinced that developmental analysis has much to offer the primary aims or concerns of evolutionary psychologists.

\section{The Role of Natural Selection in Evolutionary Theory}

We suspect that this ambivalence is due to the fact that evolutionary psychologists emphasize evolution by natural selection as opposed to evolution by epigenetic developmental mechanisms (Crawford, 2003; Tooby et al., 2003). In their commitment to adaptationism, most evolutionary psychologists continue to hold that natural selection, presumably operating on random mutations and genetic drift, is the creative force behind the design of a wide range of human behavioral and cognitive traits. In sharp contrast to this line of thinking, we argued that it is changes in development that are responsible for generating novel phenotypes, which must then pass through the filter of natural selection (Lickliter \& Honeycutt, 2003). As Bjorklund (2003) pointed out in his commentary, natural selection is the "gatekeeper" (p. 840) of evolutionary change by eliminating those phenotypes that do not fit well with their environments - it is not the creative "generator" (p. 840) of phenotypic form or phenotypic change. Simply put, natural selection is the filter that preserves reproductively successful phenotypes, which are themselves the product of individual development (Gottlieb, 2000). Tooby et al. (2003) came close to endorsing this view in their commentary, but fell short by continuing to speak of natural selection "for" traits. Natural selection does not select for phenotypic traits, as it has no agency. Rather, natural selection selects "against" individual organisms exhibiting (or lacking) specific traits or characters. Tooby et al. (2003) went on to argue that natural selection drives evolutionary processes because "it is natural selection that chooses some genes rather than others" (p. 863). In keeping with contemporary developmental systems theory, we emphasized that natural selection acts on phenotypes, not genotypes.

This view of the role of natural selection is at odds with much of the conceptual foundation of contemporary evolutionary psychology. For example, in their primer for evolutionary psychology Cosmides and Tooby (1997) proposed that

generation after generation, for more than 10 million years, natural selection slowly sculpted the human brain, favoring circuitry that was good at solving the day-to-day problems of our hunter-gatherer ancestors... Natural selection is a slow process, and there just haven't been enough generations for it to design circuits that are well-adapted to our post-industrial life. (p. 12)

This perspective led Cosmides and Tooby (1997) to propose that "behavior in the present is generated by information-processing mechanisms that exist because they solved adaptive problems in the past - in the ancestral environments in which the human line evolved" (p. 12). Evolutionary psychologists thus attempt to explain humans' modern behavioral and cognitive phenotypes by honing in on the problems our ancestors faced in the origins of the species. Thanks to design by natural selection, the minds of modern humans are seen to come equipped with predesigned domainspecific solutions (via cognitive modules) for these problems. Use of this type of phylogenetic explanation for the origins and underlying essence of human behavior and cognition is apparent across the commentaries. For example, Crawford (2003) argued that "organisms develop on the basis of many sources of information. 
One source is information about ancestral environments that is encoded in DNA" (p. 857). This phylogenetic basis of human nature is misleading and misplaced, however, as humans' behavioral and cognitive capacities are not encoded or prespecified but rather continue to evolve alongside the conditions of development (Ingold, 2002; Richardson, 1998).

As a result, we argued that the mere passing on of a genome cannot serve as a sufficient explanation for the achievement of any behavioral or cognitive outcome, although it is certainly a necessary one (Lickliter \& Honeycutt, 2003). Bjorklund (2003) and Tooby et al. (2003) appeared to agree with this view. We emphasized throughout our article that phenotypic traits are generated, not expressed, in development. In the language of developmental dynamics, form is an emergent property of the entire field of relationships within which the organism comes into being (e.g., genes, cytoplasm, neurons, hormones, diet, conspecifics). This dynamic and contingent account of trait generation underscores the key insight that understanding the mechanisms of development and evolution requires a relational concept of causality (see Gottlieb \& Halpern, 2002). The influence of genes, neuronal architecture, the physical surround, or any other factor in development can be understood only in relation to the developmental system of which they are part. Control for developmental outcomes thus resides in the structure and nature of relationships between factors or variables, not in individual variables themselves. Despite the various arguments to the contrary by our commentators, we find the application of this insight to be absent in nearly all works of evolutionary psychology. We argued that its incorporation into the field's conceptual framework would significantly alter the nature and extent of evolutionary psychology's explanations for human behavior and development. In particular, such a shift in how to attribute causation (see White, 1990) should guide evolutionary psychology to develop a more coherent framework for how to integrate genetic and experiential factors into a theory of the phenotype. Tooby et al.'s comments suggest that this agenda is beginning to receive attention within the field. We proposed that such an effort requires a multilevel framework linking genetic, neurobiological, behavioral, cognitive, social, and cultural levels and time scales to discover the relations between interactive processes making up the organism's developmental system (see Cacioppo, Bernston, Sheridan, \& McClintock, 2000; Li, 2003, for similar arguments).

\section{Relying on Prespecification: Not a Straw Man}

A second theme shared across the commentaries is that we have mischaracterized the foundational premises guiding evolutionary psychology (in particular, see Buss \& Reeve, 2003; D. L. Krebs, 2003; Tooby et al., 2003). Our commentators argued that we have constructed a straw-man version of the field that no current practitioner would endorse and that as a result, our critical examination of the underlying assumptions of evolutionary psychology is both flawed and counterproductive to advancing the field. In response to these claims, we argue that the commentaries themselves provide a number of cogent examples of the underlying assumptions we took to task in our article (Lickliter \& Honeycutt, 2003), including the widespread notion of prespecification, that phylogenetic information is somehow encoded in the genes and unfolds in the course of individual development. This view of the organism, whose essential nature and cognitive architecture is thought to be largely prespecified in advance of its development in the world, remains an underlying premise across much of evolutionary psychology. For example, Tooby and Cosmides (1989) have argued for the "innate foundation of the psyche" (p. 40). This view rests on the assumption that for any particular individual, there is some way in which information specifying its development can get into the organism before its development occurs (Ingold, 2002; Lickliter \& Berry, 1990). Thus, we have D. L. Krebs (2003) speaking of "recipes from genes" (p. 845) and Buss and Reeve (2003) discussing "evolved decision rules that influence which behaviors are produced in different ecological contexts" (p. 851). We have Crawford (2003) arguing for "genetically coded developmental processes that were designed by natural selection" (p. 856) and Bjorklund (2003) calling into play "evolved informationprocessing mechanisms, presumably represented in the genes" (p. 837).

Evolutionary psychologists do not, however, directly concern themselves with genes-the genome is an object of reference, it is not an object of study. The use of instructionistic phrases such as "recipes from genes" (D. L. Krebs, 2003, p. 845) or "encoded in the DNA" (Crawford, 2003, p. 857) by our commentators are simply intended to make the point that genetic factors are thought to predispose organisms to behave or learn or think in a particular way (see Bjorklund, 2003). This notion is an example of the phylogeny fallacy discussed in the target article (Lickliter \& Honeycutt, 2003), in which it is assumed (often implicitly) that the phenotypic traits of an individual, including significant aspects of his or her behavior and cognition, can be determined by historical events that designed the individual's genetic "program" or by environmental factors that act on the individual during his or her development. Far from being a straw man, the phylogeny fallacy is common currency in several areas within behavioral and cognitive science and remains a key construct of contemporary evolutionary psychology (Crawford \& Krebs, 1998; Gaulin \& McBurney, 2002). Although most evolutionary psychologists (including our commentators) claim to be interactionists because they acknowledge the importance of both genetic and environmental factors to understanding phenotypic development, the form of interactionism represented in the comments of Bjorklund (2003), Buss and Reeve (2003), Crawford (2003), and D. L. Krebs (2003) is a form of weak interactionism (Lerner, 2002) in which phenotypic development is seen to reflect the additive operation of two separate sources of information: one that is internal, formative, and relatively fixed (genetic) and one that is external, supportive, and relatively variable (environmental). Buss and Reeve denied the use of such dichotomous thinking in evolutionary psychology, but we find abundant evidence of it in the literature and in the commentaries themselves.

In particular, we found the comments of Tooby et al. (2003) to provide a cogent illustration of the dichotomous form of interactionism highlighted above. Their framework for the transgenerational stability of phenotypic traits and characters is based on two sets of determinants, a genetic and an environmental inheritance system. These two systems of inheritance are thought to jointly determine development. In this scheme, natural selection is seen to orchestrate the interaction between these two inheritances so that high degrees of functional order can emerge and persist across generations. According to Tooby et al., the environmental system 
is inherited by default, by virtue of simply enduring across generations, whereas the genetic system is reproduced and transmitted. Failures of reliable phenotypic development are thus attributed to either genetic mutation or environmental change (or both). We see this dual inheritance approach and its reliance on prespecification as just the type of interactionism we argued against in our article (Lickliter \& Honeycutt, 2003). We proposed that development is a self-organizing, probabilistic process in which pattern and order emerge and change as a result of transactions among developmentally relevant resources both internal and external to the organism (and not from some set of prespecified instructions). Development is not the result of the interaction of genetic and environmental factors, as neither operate as independent causes; rather, development results from the bidirectional and dynamic transaction of genes, cells, tissues, organs, and organisms during the course of individual ontogeny. Thus, genes and environment cannot be alternative or independent causes (or separate inheritance systems) for the expression of a trait or characteristic (see Wolf, 1995, for further discussion). What is inherited in reproduction is a developmental system, a complex of coacting influences, some internal (genes, cellular machinery, hormones) and some external (parental care, diet, interactions with conspecifics) to the individual organism.

We believe the persistence of dichotomous thinking in evolutionary psychology is due in large part to the continued acceptance of the distinction between proximate and ultimate cause, a hallmark of the adaptationist framework (see D. L. Krebs, 2003). In the general sense, proximate causes are seen as those acting during the life of the organism, whereas ultimate causes are characterized as those acting before the organism was conceived and that shaped its genome (Francis, 1990; Mayr, 1961). As pointed out by Crawford (2003), evolutionary psychology is primarily concerned with the ultimate causation of behavior and therefore focuses on its function or adaptive value with the aim of understanding how the behavior was designed or shaped by natural selection (J. R. Krebs $\&$ Davies, 1978). In keeping with earlier criticisms of this functionalist approach to behavior (e.g., Jamieson, 1986; O'Grady, 1984), we argued that a developmental dynamics approach offers a more comprehensive understanding of human behavior by abandoning the proximate-ultimate distinction in favor of an explicit concern with the epigenetic processes of development within and between generations (Lickliter \& Honeycutt, 2003). Contrary to the suggestions of Crawford (2003) and D. L. Krebs (2003), this approach does not deny the role (or importance) of genes in the generation of phenotypic traits and characteristics, but it does argue against any notions of the simple passing on of adaptive behaviors or cognitive strategies to the next generation. In this light, we applaud Tooby et al.'s (2003) attempt to move beyond the conceptual inadequacy of genetic programs for development. However, we find their application of "developmental" programs to be lacking as well.

We proposed that a focus on the ontogenetic construction of phenotypes, in which the organism coactively constructs itself in each generation in relation to its internal and external environment, undermines any meaningful distinction between proximate and ultimate causes of phenotypic development (Lickliter \& Honeycutt, 2003). Buss and Reeve (2003) and D. L. Krebs (2003) suggested that it is our failure to recognize the distinction between developmental accounts (proximate cause) and functional expla- nations (ultimate cause) of phenotypes that undermines our criticisms of the foundational premises of evolutionary psychology. We maintain that our rejection of this distinction is a key basis for our arguments against the underlying assumptions of most evolutionary psychologists.

On a related note, Crawford (2003) cited evidence of a particular gene (ey, or eyeless) that contributes to the development of eyes even when substituted between mice and fruit flies. Rather than incensing developmental systems theorists such as ourselves, we find such findings of homology to be especially interesting, but unlike Crawford we do not see such instances as reflecting the immortality of genes. There are numerous examples in which homologous genes have been identified that are shared across species that lead to nonhomologous morphological features, and likewise there are numerous instances in which homologous morphologies involve the expression of nonhomologous genes (Wray $\&$ Abouheif, 1998). We do not see evidence from studies of gene substitution as support for assigning causal primacy to genes. For instance, when a mouse ey gene is substituted into a fruit fly, a fruit fly eye develops, not a mouse eye (Gehring, 1998). Furthermore, ey mutant flies, which have no eyes, eventually regenerate eyes when they are allowed to breed for several generations. In addition, studies using targeted gene knockouts often find no apparent phenotypic effects, even in situations in which the genes that were targeted are known to play an important (and presumably necessary) role in phenotypic expression (S. Rose, 1999). We see such findings as providing further support for the insight that the control for any phenotypic outcome is distributed across a developmental system of components and resources, of which genes are an important part.

Crawford (2003) is mistaken to believe that when a gene has been identified to be necessary for the actualization of a given phenotypic outcome that the causal pathway begins or ends with this gene (see Robert, 2001, for further discussion). A large number of components and processes must be organized and put in motion for a gene to function at all. As we emphasized throughout our target article (Lickliter \& Honeycutt, 2003), genes are a crucial part of the developmental system, but causality is distributed across the developmental system. D. L. Krebs (2003) claimed we humans would not exist without genes-the same can be said for other developmentally necessary components such as cytoplasm, cell walls, and conspecifics.

\section{Evaluating the Methods and Accomplishments of Evolutionary Psychology}

Buss and Reeve (2003) proposed that evolutionary psychology should be evaluated on the grounds that the discipline has led to new domains of research, has generated a "rich empirical harvest" (p. 849), offers more parsimonious explanations of existing observations, and provides specific predictions in regards to undiscovered phenomena. In our view, Buss and Reeve (and Tooby et al., 2003) significantly overstated the scientific accomplishments of evolutionary psychology. Has evolutionary psychology really led to new domains of research? Certainly the domains of social exchange, social conflict, family interactions, morality, aggression, and so on listed by Buss and Reeve do not represent new topics of research in psychology. Each of these topics has a long and rich history in the behavioral sciences. What evolutionary psychology 
had added are new measures and new explanations within these domains. From an evolutionary psychologist's point of view, psychologists have traditionally been blind to the extent of how natural selection has furnished human beings' minds (Cosmides \& Tooby, 1997) and thus argue that a more concerted focus on evolved psychological mechanisms designed by natural selection will enhance explanations of human behavior and cognition and stimulate more fruitful research questions and more specific predictions than traditional psychological inquiry (Buss \& Reeve, 2003; Tooby et al., 2003).

Evolutionary psychology has certainly generated a great deal of attention within and beyond the scientific community. Within the scientific community, the "rich empirical harvest" (p. 849) to which Buss and Reeve (2003) referred should be evaluated as much on the quality of its content as on its amount. In this light, we think it important to consider a separate empirical harvest in contemporary psychological sciences that calls into question the reliability and validity of much of evolutionary psychology's empirical base and methodology. For instance, in a recent review of empirical findings, Miller, Putcha-Bhagavatula, and Pedersen (2002) found no support for the claim that men and women have evolved distinct mating preferences and strategies. DeSteno, Bartlett, Braverman, and Salovey (2002) likewise found no evidence to support the claim of sex-related differences in jealousy. Both Miller et al. and DeSteno et al. proposed and provided empirical evidence in support of the view that evolutionary psychology's meta-theory of human behavior and cognition is wrought with confounding variables and measurement artifact. Similar problems have been identified in other areas as well. Much of the empirical foundation for establishing the existence of evolved, domainspecific reasoning mechanisms (e.g., the social contract algorithm and cheater-detection module) is based on findings generated using Wason's selection task (e.g., Cosmides, 1989; Fiddick, Cosmides, \& Tooby, 2000). However, reexamination of the data from studies using this task has suggested that performance on the Wason task is highly content dependent and represents a potential case of experimental artifact (Fodor, 2000; Sperber, Cara, \& Girotto, 1995; Sperber \& Girotto, 2002).

Aside from these measurement and reliability issues, we find the validity of evolutionary psychology's claims to be lacking in at least three additional ways. First, although practitioners of evolutionary psychology claim to have identified evolved cognitive modules that have been designed by natural selection, these arguments are predominately based on data generated by interviews, surveys, and questionnaires. Evolutionary psychologists rarely validate their measures, however. For example, Buss (1995) claimed that natural selection favored women who preferred men with greater resources over those with fewer resources but presented no data to show whether mating with a wealthier man actually leads to more viable or "fitter" offspring in modern contexts or in the contexts of our distant relatives (see Fausto-Sterling, 1997). Without such empirical validation, how is one to know whether the responses of subjects on such paper-and-pencil tests really reflect how people actually behave in real-world situations? Indeed, in cases in which evolutionary psychologists predict differences in how men and women respond to sexual infidelity, no differences between the sexes are found when subjects are asked to report on their own experiences with infidelity (Harris, 2003).
A second threat to validity stems from a wealth of counterfactual observations. As a case in point, Daly and Wilson (1988, 1999) claimed that humans (and other species) possess a cognitive module to love and protect genetic offspring and that during humans' evolutionary history it was likely adaptive for men to engage in infanticide of the offspring of their mate(s) that were not their biological offspring. In support of this thesis, Daly and Wilson (1988) presented evidence that children who grow up in a household with a stepfather are at a greater risk of abuse than those raised with their biological father. To their credit, Daly and Wilson (1999) acknowledged that their hypothesis has difficulty explaining why a majority of stepfathers do not abuse their children, but they ignored other potentially counterfactual evidence such as the lesser levels of abuse in families that adopt children (H. Rose, 2000).

A third problem of validity involves the use of domain-specific cognitive modules as the proposed evolved psychological mechanisms underlying human behavior and cognition. In our target article (Lickliter \& Honeycutt, 2003) we argued that arguments for such mental modules are typically based on an outdated instructionistic view of development. We pointed out that the existence and operation of cognitive modules as explanatory mechanisms are also problematic because such modules are almost entirely inferred from the very behaviors they are invoked to explain (see Schlinger, 1996). As a result, in real-world situations one simply cannot identify which modules were guiding behavior until after the person has acted. If one accepts evolutionary psychology's claim that there are hundreds or even thousands of innate cognitive modules, then one is faced with the daunting task of characterizing the dynamics of how these modules relate to one another in real-world situations (Cervone, 2000). Given the complexity (and oftentimes ambiguity) of real-world encounters and contexts, no doubt multiple modules will often be activated (Tooby \& Cosmides, 1992). But which modules will dominate others to gain control over behavioral strategies and responses? For example, if a man is bargaining for or purchasing a food item from a woman, will his cheater-detection module, food preference module, or any of the other modules involved in decision making or sexual behaviors take control of behavior? How is one to choose whether behavior is guided by a single module or an aggregate of modules (Davies, 1996)? Evolutionary psychology is effectively silent (apart from post hoc inference and speculation) on these related questions, in large part because of the absence of developmental analysis within the field.

If evolutionary psychology were to incorporate a developmental perspective (as suggested by Bjorklund, 2003, and Tooby et al., 2003), then we predict that research attention necessarily has to shift to include not only the outcomes of development (modularity) but also a direct concern with the formative and regulatory processes of development (modularization; see Karmiloff-Smith, 2000). From a developmental perspective, mental modules do not emerge de novo and in isolation from the surrounding structuralfunctional organization that characterizes living organisms and their specific physical and social environments. If there are domain-specific modules, they must differentiate out of the available structure of the organism and its actual experiences and activities in a structured environment. Only by knowing which mental modules lead to other modules (or become more specified) and the developmental conditions of these transformations can one 
reach an explanatory or predictive understanding of the dynamics of cognitive and behavioral change. These types of concerns are at the heart of the developmental approach outlined in our article (Lickliter \& Honeycutt, 2003).

\section{Concluding Remarks}

We conclude our response by briefly responding to the charge that a developmental dynamics approach to evolutionary issues holds no water to evolutionary psychology when evaluated by the criteria proposed by Buss and Reeve (2003; theoretical cogency, interdisciplinary consistency, and empirical harvest). We suggest that this comparison is largely irrelevant in light of the intent of our article (Lickliter \& Honeycutt, 2003). We did not set out to provide a specific alternative to evolutionary psychology. Rather, we focused on exploring whether the conceptual framework for understanding development and evolution espoused by proponents of evolutionary psychology is outdated and implausible in light of recent advances in the biological sciences. We believe the evidence we reviewed provides a compelling basis for concluding that several of the foundational premises of contemporary evolutionary psychology are indeed questionable in this light. Although we agree in principle with Buss and Reeve (2003) and D. L. Krebs (2003) that science can advance by measuring the merits of two or more alternative or competing theories, if the usefulness of a theory (or in this case a meta-theory) can be called into question by the weight of available contradictory evidence, then a defined alternative hardly seems required to critically question the assumptions guiding current evolutionary thinking within psychology.

That being said, we did attempt to provide an initial outline of how to better approach the issues of behavioral development and evolution in our article (Lickliter \& Honeycutt, 2003). Our suggestions centered on the value and dividends of focusing on the processes that characterize reproduction and heredity. To date, there is no overarching theory that adequately explains the breadth of hereditary processes (i.e., those processes and resources involved in contributing to enduring phenotypic stability across generations and to the generation of phenotypic novelty). We believe such a theory is attainable, but in our opinion it has yet to receive the empirical or theoretical attention it deserves (but see Gottlieb, 2002; Johnston \& Gottlieb, 1990; Newman \& Muller, 2000; Oyama et al., 2001; Schlichting \& Pigliucci, 1998). Given that natural selection can only be invoked to explain the frequencies of traits in a population (and not why individual organisms have the traits they do), it seems clear that much is to be gained in evolutionary theory from a fuller understanding of how traits are generated and maintained in developmental processes. To quote Sober (1995),

This is not because selection says nothing about individuals; on the contrary, given that individuals have various traits, selection explains why individuals are eliminated or not and why they reproduce to the degree they do. However, selection does not explain why individuals have their traits. The latter explanandum is properly addressed by describing the mechanism of heredity. (p. 396)

Our "alternative" to evolutionary psychology is thus one of description and experimentation with the goal of showing how one generation leads to (i.e., sets up the developmental conditions and resources for) the next. We argue that the developmental dynamics approach outlined in our article (Lickliter \& Honeycutt, 2003) is well suited for this endeavor in that adequate explanations of phenotypic stability and variability must include reference to the experiential history of particular organisms developing in particular, historically situated contexts. In other words, understanding the persistence and change of phenotypic forms over time must include an empirical focus on the activities and resources that generate them. By explicitly not making a distinction between genetic and environmental systems of inheritance, a developmental dynamics approach can provide an evolutionary perspective of human behavior and cognition that moves beyond outdated notions of genetically or environmentally determined development. This agenda would entail a radical and explicitly developmental alternative to the current aims and methods of evolutionary psychology.

\section{References}

Alberch, P. (1982). The generative and regulatory roles of development in evolution. In D. Mosakowski \& G. Roth (Eds.), Environmental adaptation and evolution (pp. 19-36). Stuttgart, Germany: Fischer-Verlag.

Bjorklund, D. F. (2003). Evolutionary psychology from a developmental systems perspective: Comment on Lickliter and Honeycutt (2003). Psychological Bulletin, 129, 836-841.

Buss, D. M. (1995). Evolutionary psychology: A new paradigm for psychological science. Psychological Inquiry, 6, 1-30.

Buss, D. M., \& Reeve, H. K. (2003). Evolutionary psychology and developmental dynamics: Comment on Lickliter and Honeycutt (2003). Psychological Bulletin, 129, 848-853.

Cacioppo, J. T., Bernston, G. G., Sheridan, J. F., \& McClintock, M. K (2000). Multilevel integrative analysis of human behavior: Social neuroscience and the complementing nature of social and biological approaches. Psychological Bulletin, 126, 829-843.

Cervone, D. (2000). Evolutionary psychology and explanation in personality psychology: How do we know which module to invoke? American Behavioral Scientist, 43, 1001-1014.

Cosmides, L. (1989). The logic of social exchange: Has natural selection shaped how humans reason? Cognition, 31, 187-276.

Cosmides, L., \& Tooby, J. (1997). Evolutionary psychology: A primer. Retrieved January 14, 2002, from the University of California, Santa Barbara, Center for Evolutionary Psychology Web site: http://www .psych.ucsb.edu/research/cep/primer.html

Crawford, C. B. (2003). A prolegomenon for a more viable evolutionary psychology-The myth and the reality: Comment on Lickliter and Honeycutt (2003). Psychological Bulletin, 129, 854-857.

Crawford, C., \& Krebs, D. L. (1998). Handbook of evolutionary psychology: Ideas, issues, and applications. Hillsdale, NJ: Erlbaum.

Daly, M., \& Wilson, M. (1988). Homicide. New York: Aldine de Gruyter Hawthorne.

Daly, M., \& Wilson, M. (1999). The truth about Cinderella: A Darwinian view of parental love. New Haven, CT: Yale University Press.

Davies, P. S. (1996). Evolutionary theory in cognitive psychology. Minds and Machines, 6, 445-462.

DeSteno, D., Bartlett, M. Y., Braverman, J., \& Salovey, P. (2002). Sex differences in jealousy: Evolutionary mechanism or artifact of measurement? Journal of Personality and Social Psychology, 83, 1103-1116.

Fausto-Sterling, A. (1997). Beyond difference: A biologist's perspective. Journal of Social Issues, 53, 233-258.

Fiddick, L., Cosmides, L., \& Tooby, J. (2000). No interpretation without representation: The role of domain-specific representations in the Wason selection task. Cognition, 77, 1-79.

Fodor, J. (2000). Why are we so good at detecting cheaters? Cognition, 75 , $29-32$. 
Francis, R. C. (1990). Causes, proximate and ultimate. Biology and Philosophy, 5, 401-415.

Gaulin, S. J. C., \& McBurney, D. H. (2002). Psychology: An evolutionary approach. New York: Prentice Hall.

Gehring, W. (1998). Master control genes in development and evolution. New Haven, CT: Yale University Press.

Gilbert, S. F. (2000). Developmental biology (6th ed.). Sunderland, MA: Sinauer.

Gottlieb, G. (1992). Individual development and evolution: The genesis of novel behavior. New York: Oxford University Press.

Gottlieb, G. (1998). Normally occurring environmental and behavioral influences on gene activity: From central dogma to probabilistic epigenesis. Psychological Review, 105, 792-802.

Gottlieb, G. (2000). Environmental and behavioral influences on gene activity. Current Directions in Psychological Science, 9, 93-97.

Gottlieb, G. (2002). Developmental-behavioral initiation of evolutionary change. Psychological Review, 109, 211-218.

Gottlieb, G., \& Halpern, C. T. (2002). A relational view of causality in normal and abnormal development. Development and Psychopathology, $14,421-435$.

Gould, S. J. (2002). The structure of evolutionary theory. Cambridge, MA: Harvard University Press.

Hall, B. K. (1999). Evolutionary developmental biology (2nd ed.). Boston: Kluwer.

Harris, C. R. (2003). A review of sex differences in sexual jealousy, including self-report data, psychophysiological responses, interpersonal violence, and morbid jealousy. Personality and Social Psychology Review, 7, 102-128.

Ingold, T. (2002). Between evolution and history: Biology, culture, and the myth of human origins. Proceedings of the British Academy, 112, 43-66.

Jablonka, E. (2001). The systems of inheritance. In S. Oyama, P. E. Griffiths, \& R. D. Gray (Eds.), Cycles of contingency: Developmental systems and evolution (pp. 99-116). Cambridge, MA: MIT Press.

Jamieson, I. G. (1986). The functional approach to behavior: Is it useful? American Naturalist, 127, 195-208.

Johnston, T. D., \& Gottlieb, G. (1990). Neophenogenesis: A developmental theory of phenotypic evolution. Journal of Theoretical Biology, 147, 471-495.

Karmiloff-Smith, A. (2000). Why babies' brains are not Swiss army knives. In H. Rose \& S. Rose (Eds.), Alas poor Darwin: Arguments against evolutionary psychology (pp. 209-228). New York: Harmony Books.

Keller, E. F. (2000). The century of the gene. Cambridge, MA: Harvard University Press.

Kirschner, M., \& Gerhart, J. (1998). Evolvability. Proceedings of the National Academy of Sciences, USA, 95, 8420-8427.

Krebs, D. L. (2003). Fictions and facts about evolutionary approaches to human behavior: Comment on Lickliter and Honeycutt (2003). Psychological Bulletin, 129, 842-847.

Krebs, J. R., \& Davies, N. B. (1978). An introduction to behavioral ecology. Sunderland, MA: Sinauer.

Lerner, R. M. (2002). Concepts and theories of human development (3rd ed.). Mahwah, NJ: Erlbaum.

Li, S.-C. (2003). Biocultural orchestration of developmental plasticity across levels: The interplay of biology and culture in shaping the mind and behavior across the life span. Psychological Bulletin, 129, 171-194.

Lickliter, R., \& Berry, T. D. (1990). The phylogeny fallacy: Developmental psychology's misapplication of evolutionary theory. Developmental Review, 10, 348-364.
Lickliter, R., \& Honeycutt, H. (2003). Developmental dynamics: Toward a biologically plausible evolutionary psychology. Psychological Bulletin, 129, 819-835.

Mayr, E. (1961, November 10). Cause and effect in biology. Science, 134, $1501-1506$.

Miller, L. C., Putcha-Bhagavatula, A., \& Pedersen, W. C. (2002). Men's and women's mating preferences: Distinct evolutionary mechanisms? Current Directions in Psychological Science, 11, 88-93.

Moss, L. (2003). What genes can't do. Cambridge, MA: MIT Press.

Newman, S. A., \& Muller, G. B. (2000). Epigenetic mechanisms of character origination. Journal of Experimental Zoology, 288, 304-317.

O'Grady, R. T. (1984). Evolutionary theory and teleology. Journal of Theoretical Biology, 107, 563-578.

Oyama, S. (1985). The ontogeny of information. Cambridge, England: Cambridge University Press.

Oyama, S., Griffiths, P. E., \& Gray, R. D. (2001). Cycles of contingency: Developmental systems and evolution. Cambridge, MA: MIT Press.

Raff, R. A. (1996). The shape of life. Chicago: University of Chicago Press.

Richardson, K. (1998). The origins of human potential: Evolution, development and psychology. London: Routledge.

Robert, J. S. (2001). Interpreting the homeobox: Metaphors of gene action and activation in development and evolution. Evolution and Development, 3, 287-295.

Rose, H. (2000). Colonizing the social sciences? In H. Rose \& S. Rose (Eds.), Alas poor Darwin: Arguments against evolutionary psychology (pp. 127-153). New York: Harmony Books.

Rose, S. (1999). Precis of Lifelines: Biology, freedom, determinism. Behavioral and Brain Sciences, 22, 871-921.

Schlichting, C. D., \& Pigliucci, M. (1998). Phenotypic evolution: A reaction norm perspective. Sunderland, MA: Sinauer.

Schlinger, H. D. (1996). How the human got its spots. Skeptic, 4, 68-76.

Sober, E. (1995). Natural selection and distributive explanation: A reply to Neander. British Journal for the Philosophy of Science, 46, 384-397.

Sperber, D., Cara, F., \& Girotto, V. (1995). Relevance theory explains the selection task. Cognition, 52, 3-39.

Sperber, D., \& Girotto, V. (2002). Use or misuse of the selection task? Rejoinder to Fiddick, Cosmides, and Tooby. Cognition, 85, 277-290.

Tooby, J., \& Cosmides, L. (1989). Evolutionary psychology and the generation of culture: I. Theoretical considerations. Ethology and Sociobiology, 10, 29-49.

Tooby, J., \& Cosmides, L. (1992). The psychological foundations of culture. In J. Barkow, L. Cosmides, \& J. Tooby (Eds.), The adapted mind: Evolutionary psychology and the generation of culture (pp. 19136). New York: Oxford University Press.

Tooby, J., Cosmides, L., \& Barrett, H. C. (2003). The second law of thermodynamics is the first law of psychology-Evolutionary developmental psychology and the theory of tandem, coordinated inheritances: Comment on Lickliter and Honeycutt (2003). Psychological Bulletin, $129,858-865$.

Waddington, C. (1941, January 25). The evolution of developmental systems. Nature, 147, 108-109.

White, P. A. (1990). Ideas about causation in philosophy and psychology. Psychological Bulletin, 108, 3-18.

Wolf, U. (1995). The genetic contribution to the phenotype. Human Genetics, 95, 127-148.

Wray, G. A., \& Abouheif, E. (1998). When is homology not homology? Current Opinion in Genetics \& Development, 8, 675-680.

Received May 28, 2003

Accepted June 2, 2003 